\title{
The Dangeard and Explorer canyons, South Western Approaches UK: Geology, sedimentology and newly discovered cold-water coral mini-mounds.
}

\author{
Heather A. Stewart ${ }^{\mathrm{a} 1}$, Jaime S. Davies ${ }^{\mathrm{b}}$, Janine Guinan ${ }^{{ }^{*}}$ and Kerry L. Howell ${ }^{\mathrm{b}}$ \\ ${ }^{a}$ British Geological Survey, Murchison House, West Mains Road, Edinburgh, EH9 3LA, UK. \\ ${ }^{b}$ University of Plymouth, School of Biological Sciences, University of Plymouth, Drake Circus, Plymouth, PL4 \\ $8 A A, U K$. \\ 'Marine Institute, Rinville, Oranmore, County Galway, Ireland. \\ "Current address: Geological Survey of Ireland, Beggars Bush, Haddington Road, Dublin 4, Ireland.
}

\section{ABSTRACT}

The Celtic Margin is a complex area in terms of sedimentary dynamics and evolution, with a number of submarine canyons dissecting the continental slope and outer continental shelf. The complex terrain and diverse range of sea-bed sediments play a part in submarine canyons being described as areas of high habitat heterogeneity. This study has concentrated on the heads of two canyons: Dangeard (also known as Dangaard) and Explorer (first named here) located in UK territorial waters, in water depths between 138 and $1165 \mathrm{~m}$. Multibeam echosounder, 2D reflection seismic and photographic ground-truthing data have been combined to map the sea-bed geomorphology, sedimentary features and canyon megafauna of these canyons. In addition, two previously unknown provinces of cold-water coral (CWC) mini-mounds were discovered on the interfluves of the Dangeard and Explorer canyons.

The study area comprises a dendritic network of gullies feeding into the canyon thalwegs. Amphitheatre rims, where slope angles are commonly in excess of $20^{\circ}$, occur along the margins and heads of both canyons and are interpreted as drainage basins indicative of retrogressive mass-wasting in a shelfward direction.

The CWC mini-mounds occur in water depths between $250 \mathrm{~m}$ and $410 \mathrm{~m}$, with more than 400 mounds identified. They are up to $3 \mathrm{~m}$ in height and 50-150 $\mathrm{m}$ in diameter with no sub-surface expression, suggesting these mounds are, in geological terms, relatively young and possibly Holocene in age. Biological analyses revealed that the mounds form a habitat for ophiuroids and Munida associated with Lophelia pertusa coral rubble, suggesting these mini-mounds are not present-day living features.

Keywords: Cold-water coral mounds; Geomorphology; Lophelia pertusa; Multibeam sonar; Submarine canyons; Turbidity currents

\footnotetext{
${ }^{1}$ Corresponding author email: hast@bgs.ac.uk

Corresponding author telephone: +441316671000
}

\section{REFERENCE}

Stewart, h A, DaVies, J S, Guinan, J C, and HowelL, K L. 2013. The Dangeard and Explorer Canyons, South Western Approaches UK: Geology, sedimentology and newly discovered cold-water coral mini-mounds. Deep-Sea Research II, Topical Studies in Oceanography. doi: http://dx.doi.org/10.1016/i.dsr2.2013.08.018 


\section{Introduction}

Submarine canyons are topographically complex features (Harris and Whiteway, 2011) incising most of the world's continental slopes (e.g. Brodeur, 2001 and Hickey, 1995). Processes such as turbidity currents, the capture of along-shelf/-slope sediment, resuspension by internal tides and waves, and dense shelf water cascading result in either flushing of the canyon or the downslope deposition of sediments and organic matter (Canals et al., 2006, De Stigter et al., 2007, Hall et al., this issue, Huvenne et al., 2011, "Euroleón" Cruise Shipboard Party, 2011, Palanques et al., 2006, Palanques et al., 2009, Puig et al., 2008 and Ulses et al., 2008). The complex terrain and diverse range of sea-bed composition contribute to submarine canyons being described as areas of high habitat heterogeneity (Schlacher et al., 2007).

Canyons are known to support cold-water corals (CWC) (Huvenne et al., 2011, Morris et al., 2013 and Orejas et al., 2009), while CWC mounds, formed by framework building scleractinian corals such as Lophelia pertusa, are common along the north-western European margin and occur in distinct regions on the Celtic Margin and Porcupine Seabight (Wheeler et al., 2007). Within the Porcupine Seabight numerous mound provinces exist, in which mounds vary in size up to giant mounds of up to $160 \mathrm{~m}$ high and up to $5 \mathrm{~km}$ in length: Hovland mounds, Magellan mounds and the Belgica mounds ( De Mol et al., 2002, Hovland et al., 1994, Huvenne et al., 2009a, Van Rooij et al., 2009 and Wheeler et al., 2007). The process of accretion of these large mounds is not well understood although coring through the Challenger Mound by IODP Expedition 307 revealed gradual reef stacking over the course of $2.6 \mathrm{Ma}$. However, the record is discontinuous with glacially derived sediments often missing (Huvenne et al., 2009a and Thierens et al., 2009). Smaller CWC mounds, often termed 'mini-mounds', are also documented, such as the Moira Mounds that are 20-35 $\mathrm{m}$ in diameter and 3-11 $\mathrm{m}$ high and form part of the Belgica Mound province (Wheeler et al., 2011). The Moira Mounds may serve as an analogue for mini-mounds, up to $5 \mathrm{~m}$ high, observed on Odet Spur located between Odet Canyon and Guilvinec Canyon (De Mol et al., 2011). The Moira Mounds have no sub-surface expression so are proposed as initiated during Holocene times and it is suggested that the coalescence of individual mounds, or clusters of mounds, may result in the formation of large coral carbonate mounds, examples of which are located nearby, such as the Challenger Mound ( Huvenne et al., 2009a, Thierens et al., 2009 and Wheeler et al., 2011).

The Celtic Margin is a west-northwest-east-southeast trending passive margin characterised by a steep continental slope incised by a large number of canyons (Fig. 1; Huthnance et al., 2001; Mulder et al., 2012). The spurs and canyons of the Celtic Margin and the Armorican Margin to the southeast are organised into submarine drainage basins (Bourillet and Lericolais, 2003). The Explorer and Dangeard canyons presented in this paper are part of the Grande Sole drainage basin (Fig. 1), which was fed by melt water from the Irish Sea sourced from the disintegrating British Ice Sheets (Zaragosi et al., 2000 and Zaragosi et al., 2006). The Grande Sole drainage system feeds the Celtic deep-sea fan system via the Whittard Canyon (ig. 1).

The main aim of this study was (1) to map the geomorphology and near sea-bed sedimentary succession of the Dangeard and Explorer canyons, (2) to define and map the distribution of canyon mega-fauna and assess the presence of any anthropogenic impacts that may have affected these communities, (3) map the distribution, characterise the associated macro-fauna and understand the ecological and geological significance of newly discovered mini-mounds, and (4) to determine whether they are comparable to other provinces of mini-mounds, such as the Darwin and Moira mounds, which have been found to be of ecological and conservation interest, and may represent the initial growth stage of carbonate mound accretion. 


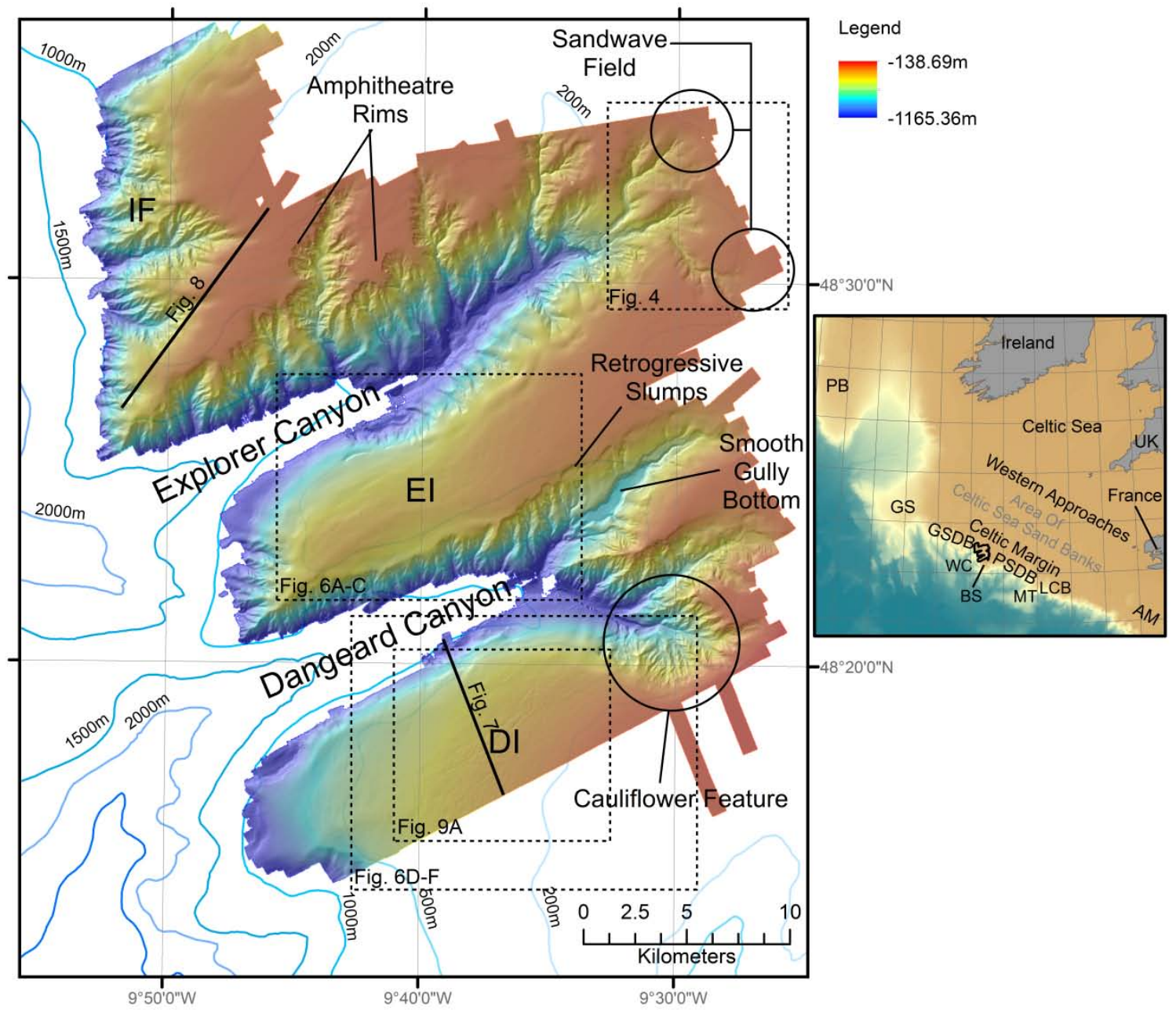

Fig. 1. Shaded relief map of the high-resolution multibeam bathymetry data acquired over the study area. The shaded relief image reveals the morphology of the Dangeard and Explorer canyons and the flank of a third canyon located in Irish territorial waters. See inset map for location. Generalised bathymetric contours on main map and shaded relief on inset map are derived from GEBCO (www.gebco.net). AM - Armorican Margin, BS - Brenot Spur, DI - Dangeard Interfluve, EI - Explorer Interfluve, GS - Goban Spur, GSDB - Grande Sole Drainage Basin, IF - eastern flank of a third canyon located in Irish territorial waters, LCB - La Chapelle Bank, MT - Meriadzek Terrace, PB - Porcupine Bank, PSDB Petite Sole Drainage Basin, WC - Whittard Canyon.

\section{Regional setting}

\subsection{Geological setting}

The geological framework of the Celtic Margin was formed during the Early-Cretaceous rifting episode associated with the opening of the North Atlantic (Evans, 1990). The post-rift succession forms a westerlydipping wedge comprising roughly equal thicknesses of Cretaceous (mostly chalk), Paleogene (limestones and mudstones) and Neogene (calcarenites-lutites) deposits that together attain a maximum thickness greater than $1400 \mathrm{~m}$ on the outer shelf (Evans, 1984).

The Early Cretaceous sedimentary succession comprises a thin sequence of shallow-marine clastics resting unconformably on Permo-Triassic or Jurassic sediments (Evans, 1990). Sea level rise associated with the opening of the North Atlantic changed the depositional environment from shallow- to deep-marine resulting in deposition of a thick sequence of chalk during Late Cretaceous and Palaeocene times (Evans, 1990). Local sea level remained high, approximately 200-350 m above present day, and only began to fall during Oligocene times (Haq et al., 1987). 
Deposition during the Cenozoic was controlled by two main Alpine orogenic events, the first, in Mid Eocene times triggered Oligocene compression and folding of Palaeocene-Oligocene sediments (Evans, 1990). The second, caused by the Western Alps collision, resulted in general uplift of approximately $100 \mathrm{~m}$ in the Channel area during Late Miocene times (Evans, 1990). It is the second of these Alpine events described above that has had the most profound influence on the study area. The alpine inversion event caused the seaward deposition of two prograding, deltaic wedges during the Miocene (the Jones and Cockburn formations), which downlap onto the unconformable surface of the Late Cretaceous Chalk. The present-day upper continental slope and outer continental slope is underlain by Pliocene to Pleistocene sediments (Little Sole Formation) that thin landward onto the outer continental shelf and oceanward below a depth of around $1500 \mathrm{~m}$. Submarine canyons of the upper continental slope were incised during a number of episodic sea level low stands during Plio-Pleistocene times (Bourillet et al., 2003, Evans, 1990 and Evans and Hughes, 1984). There is no evidence to suggest that canyon cutting is ongoing today although active retrogressive headwall erosion has occurred since the last glacial maximum (21 ka BP) (Cunningham et al., 2005, Evans, 1990, Evans and Hughes, 1984 and Scourse et al., 2009).

A key feature of the Celtic Margin is the growth of a suite of linear tidal sand ridges located on the outer continental shelf of the Celtic Sea, immediately landward from the study area. These features generally trend northeast-southwest extending from the vicinity of the continental shelf break. The largest of these ridges is up to $200 \mathrm{~km}$ long, $55 \mathrm{~m}$ high and $15 \mathrm{~km}$ wide. Scourse et al. (2009) report that the main period of growth for these ridges was between 20 and $12 \mathrm{cal}$ ka with some later growth of the most southerly ridges as late as $10 \mathrm{cal} \mathrm{ka.} \mathrm{It} \mathrm{is} \mathrm{proposed} \mathrm{that} \mathrm{strong} \mathrm{tidal} \mathrm{transport} \mathrm{of} \mathrm{sediments} \mathrm{into} \mathrm{the} \mathrm{canyon} \mathrm{heads,} \mathrm{located} \mathrm{on}$ the outer continental shelf, occurred during the same time period contributing to turbidite activity and growth of the deep-sea fan systems (Bourillet et al., 2006 and Scourse et al., 2009).

\subsection{Oceanographic setting}

High-energy hydrodynamics characterise the Celtic Margin with spring tides and storm surges influencing the transport of sediment from the near shore to the shelf-edge and margin slope (Kenyon and Stride, 1970, Reynaud et al., 1999 and Zaragosi et al., 2000). The study area is influenced by two main water masses: an upper layer described as the Eastern North Atlantic Water (ENAW; a component of the North Atlantic Current) from the thermocline (a seasonal surface layer of up to 50-100 m thickness) down to $800 \mathrm{~m}$ water depth; and the Mediterranean Outflow Water (MOW) from $800 \mathrm{~m}$ to $1200 \mathrm{~m}$ water depth (Dullo et al., 2008, Le Boyer et al., 2013 and van Weering et al., 1998). Below the MOW, the North Atlantic Deep Water, which includes a component of Labrador Sea Water, extends from $1200 \mathrm{~m}$ down to 3000-3500 m water depth (van Weering et al., 1998). The flow of the ENAW seems to be partly carried by along-slope currents that flow northwards along the northeast Atlantic Margin (Le Boyer et al., 2013 and Pingree and Le Cann, 1989). The MOW is characterised by increased salinity and potential temperature when compared to the over- and under-lying water masses (Dullo et al., 2008). Internal waves and tides are considered important to sediment transport and sedimentation at the northeast Atlantic Margin (Mulder et al., 2012).

Whilst long- and short-term current measurements on the Celtic Shelf and shelf-edge are available, measurements of near-bed (within $3 \mathrm{~m}$ of the sea bed) currents with direct relevance to sediment transport of re-suspended material are scarce. Results from the Ocean Margins EXchange Programme (Wollast and Chou, 2001) indicate that along-slope residual current velocities of $0.05 \mathrm{~m} \mathrm{~s}^{-1}$ exist at the shelf break and large tidal currents generate internal tides $\left(>0.05 \mathrm{~m} \mathrm{~s}^{-1}\right)$ with vertical displacements of up to $150 \mathrm{~m}$ (Huthnance et al., 2001).

The study area is influenced by ebb-dominated tidal currents operating at the shelf edge. Reynaud et al. (1999) describe the interplay between tides and waves at the Celtic Sea shelf edge in water depths comparable to those in the study area. The area is described as being swept by tidal currents that locally reach $0.9 \mathrm{~m} \mathrm{~s}^{-1}$ one metre above the sea bed around La Chapelle Bank (Heathershaw et al., 1987) located 
southeast along the margin from the study area, whilst northwest of the study area in the vicinity of the Goban Spur currents of $0.2 \mathrm{~m} \mathrm{~s}^{-1}$ are more typical (Huthnance et al., 2001).

\section{Data and methods}

The heads of Dangeard and Explorer canyons were surveyed during the MESH canyons cruise on board of the R/V Celtic Explorer from 4th to 18th June 2007 (Fig. 1).

\subsection{Multibeam echosounder data}

Multibeam bathymetry (Fig. 1) and backscatter data (Fig. 2) were acquired over an area of $1106 \mathrm{~km}^{2}$ using the vessel's hull-mounted Kongsberg Simrad EM1002 system, which operates at a frequency of 93-95 kHz and has the capability of acquiring data down to around $1000 \mathrm{~m}$ water depth (Stewart and Davies, 2007). A fixed swath width of $660 \mathrm{~m}$ was employed throughout the survey, maintaining a beam spacing of at least $5 \%$ of the water depth. Multibeam echosounder data were acquired to meet the International Hydrographic Organisation (IHO) S44 Order 2 standard. See Stewart and Davies (2007) for full details on the EM1002 calibration and data quality control performed during the survey. The high-resolution bathymetric data were processed using CARIS HIPS and SIPS hydrographic data processing software. Bathymetric data were corrected for tidal variations using predicted tides generated from Polpred software developed at the Proudman Oceanographic Laboratory. Once fully processed and cleaned the data were gridded at $25 \mathrm{~m}$ before being modelled to reveal the topography of the sea bed (Fig. 1). Minimum water depths encountered within the study area were $138 \mathrm{~m}$ with maximum water depths of $1165 \mathrm{~m}$ encountered (Fig. 1). Additional layers were derived from the multibeam bathymetry and were generated in ArcGIS using the spatial analyst (slope, rugosity and aspect) and Benthic Terrain Modeller extensions (Bathymetric Positioning Index (BPI); Wright et al., 2005). BPI is a measure of where a referenced location is relative to the locations around it. Positive BPI values denote features and regions higher than the surrounding area, negative values denote features and regions lower than the surrounding area. Values around zero are either flat areas where the slope is near zero or areas of constant slope (Weiss, 2001). Bathymetric position is a scale-dependent phenomenon (Weiss, 2001) therefore both fine- and broad-scale BPI data sets are generated, where the fine scale BPI layer is calculated using a smaller analysis neighbourhood than the broad scale layer. Backscatter intensity data were acquired simultaneously with the bathymetric data (Fig. 2). The original raw data registered during the survey were processed using FM Geocoder (Fonseca and Calder, 2005). FM Geocoder corrects the backscatter intensities registered by the multibeam echosounder system, and then geometrically corrects and positions each acoustic sample in a backscatter mosaic. The backscatter intensity data were gridded at $25 \mathrm{~m}$.

\subsection{Seismic data}

Seismic data were collected with two systems running simultaneously, the British Geological Survey (BGS) multi-tip sparker system and the BGS deep-tow boomer system (Stewart and Davies, 2007) (Fig. 3a). The multi-tip sparker system was run at between 750 and $1500 \mathrm{~J}$ per shot and was fired once every $6 \mathrm{~s}$, interleaved with the firing of the deep-tow boomer system. For the sparker system, a SIG 7 channel, $10 \mathrm{~m}$ hydrophone streamer and SIG preamplifier with all channels summed to give a single channel output was used. The summed output was fed into the BGS own designed amplifier that incorporates low-pass and antialias filters and adjustable analogue gain to compensate for acoustic losses with water depth. The sparker signal was sampled at $5000 \mathrm{~Hz}$. The deep-tow boomer system was run at $500 \mathrm{~J}$ per shot and was fired 3-4 times in every $6 \mathrm{~s}$, depending on water depth and the height of the tow fish from the sea bed, interleaved with the firing of the sparker system. The deep-tow boomer pre-amplifier control unit has an inbuilt depth compensation unit controlled by a pressure sensor in the tow fish to allow for winching in and out of the cable during survey. The depth compensation also acted as a good heave filter. The $2 \mathrm{~m}, 6$ element, deep water BGS streamer was used during this cruise with the signal fed into the deep-tow boomer control unit. 
The depth compensated analogue signal output was also fed into the BGS own designed amplifier described above. The deep-tow boomer signal was sampled at 10,000 Hz. A CODA DA200 was used to record the two seismic sources simultaneously. Layback was applied post-cruise and no additional processing was carried out. A total of 320 line kilometres of seismic data were acquired (i․ 3 a).

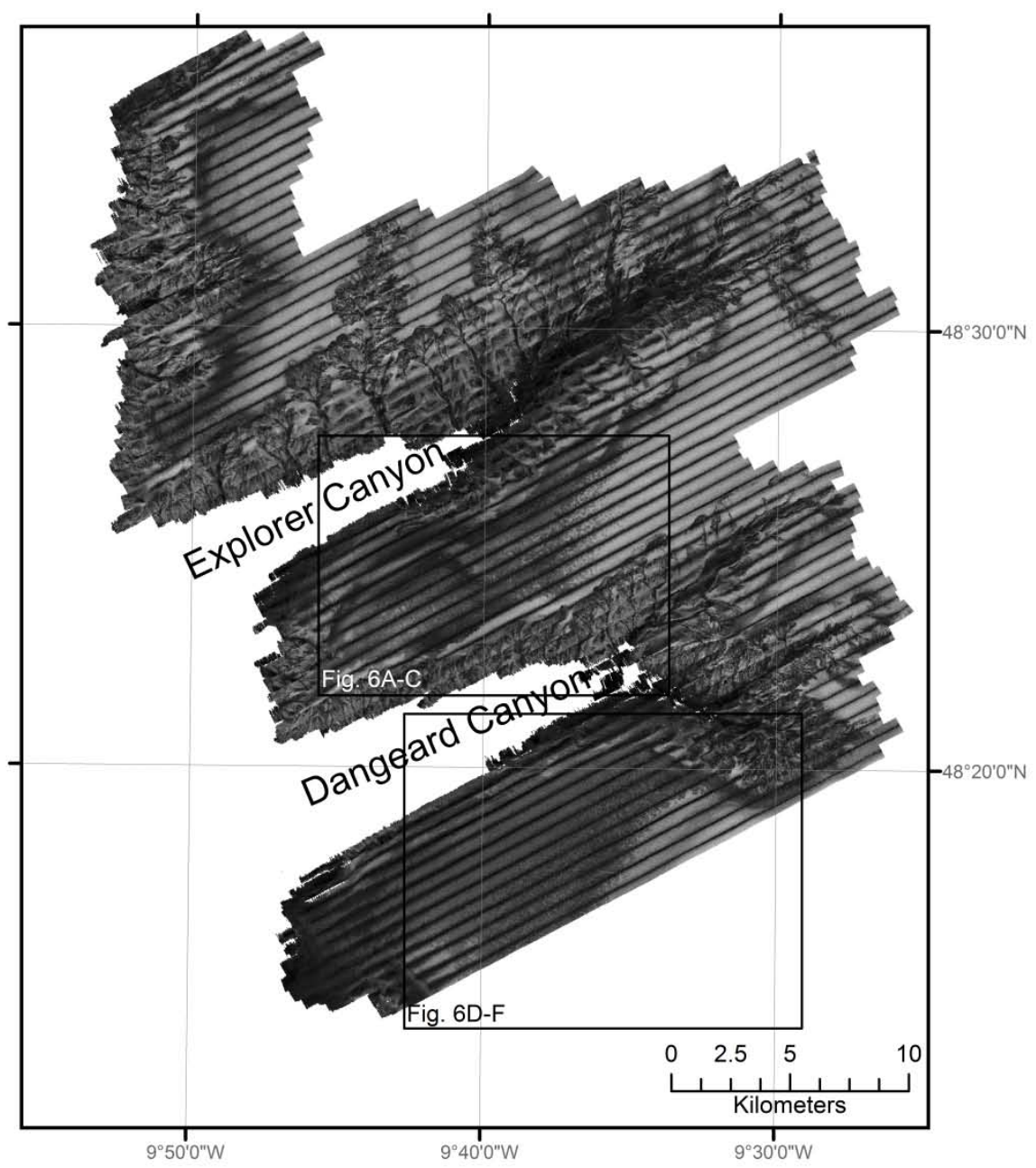

Fig. 2. Mosaic of the high-resolution multibeam backscatter intensity data acquired over the study area. Low backscatter values are indicated by areas of pale grey, high backscatter areas are indicated by areas of dark grey/black.

\subsection{Video and image ground-truthing data}

A comprehensive suite of camera and video 'ground-truthing' sites were visited during the survey to characterise the ecology and sea-bed sediments of the study area (Fig. 3b). A Seatronics drop frame system with both digital video and stills cameras was utilised for this purpose (Stewart and Davies, 2007). Video transects were selected during operations based on the interpretation of the multibeam bathymetry and backscatter data. The transects were selected to cover a range of different geomorphologies, sea-bed sediment type and water depth. The Seatronics system was fitted with a DTS 6000 digital video telemetry system and a 5 megapixel Kongsberg Simrad digital stills camera mounted opposite each other at oblique angles (video: $24^{\circ}$; stills: $22^{\circ}$ ) to the sea bed for optimal sea bed coverage and species identification. The frame was also fitted with sensors to record depth, altitude and temperature, and an ultra-short baseline (USBL) beacon to collect accurate positional data for the frame. The USBL provided accurate positional data for some transects, but malfunctioned during the course of the survey. As a result positional data were taken from the ships T-frame, from which the drop frame camera was deployed. A comparison between vessel position and USBL position on previous transects (in ArcGIS) revealed a high degree of confidence for the 
vessel positional data being sufficiently accurate for use with remaining transects. The accuracy of the vessel position [within $30 \mathrm{~m}$ of the USBL (Stewart and Davies, 2007)] was adequate for acquisition of the remaining camera transects. The field of view was calibrated by attaching a gridded quadrat of known dimensions (grid cell size of $4.9 \mathrm{~cm} \times 5.5 \mathrm{~cm}$ ). The field of view was calibrated for 'on bottom' (drop frame fully landed on the sea bed) and at 1,2 and $3 \mathrm{~m}$ off bottom to aid in quantitative analysis of fauna and particle size discrimination of the sea bed.

Video transects were between $250 \mathrm{~m}$ and $1200 \mathrm{~m}$ long. For the majority of transects, vessel speed was approximately 0.5 knots (minimum 0.3 and maximum 0.7 knots), with most transects lasting between 0.5 and $1.5 \mathrm{~h}$. The drop frame was towed in the water column between 1 and $3 \mathrm{~m}$ (dependant on sea-bed type, topography and near sea-bed currents) above the sea bed. At the beginning of each transect, starting from when the sea floor became visible, a 2-3 min stabilisation period was allowed before sampling commenced. A total of 44 video transects were acquired, totalling $23 \mathrm{~h}$ of footage and more than 5000 still images obtained across the survey area. Of these images, 1073 were sampled at 1 min intervals. Following inspection, 199 of these images were discarded either due to being out of focus, obscured by silt clouds, or too high off the sea bed to allow accurate identification of organisms or sea-bed sediment and were not included in the analysis.

For each digital stills image acquired: (1) a sea-bed sediment classification was assigned based on the modified Folk diagram (Folk, 1954 and Long, 2006); (2) all visible organisms (>1 cm at their widest point) were identified as distinct morphospecies (morphotypes) and assigned an Operational Taxonomic Unit (Davies, 2012 and Davies et al., this issue).

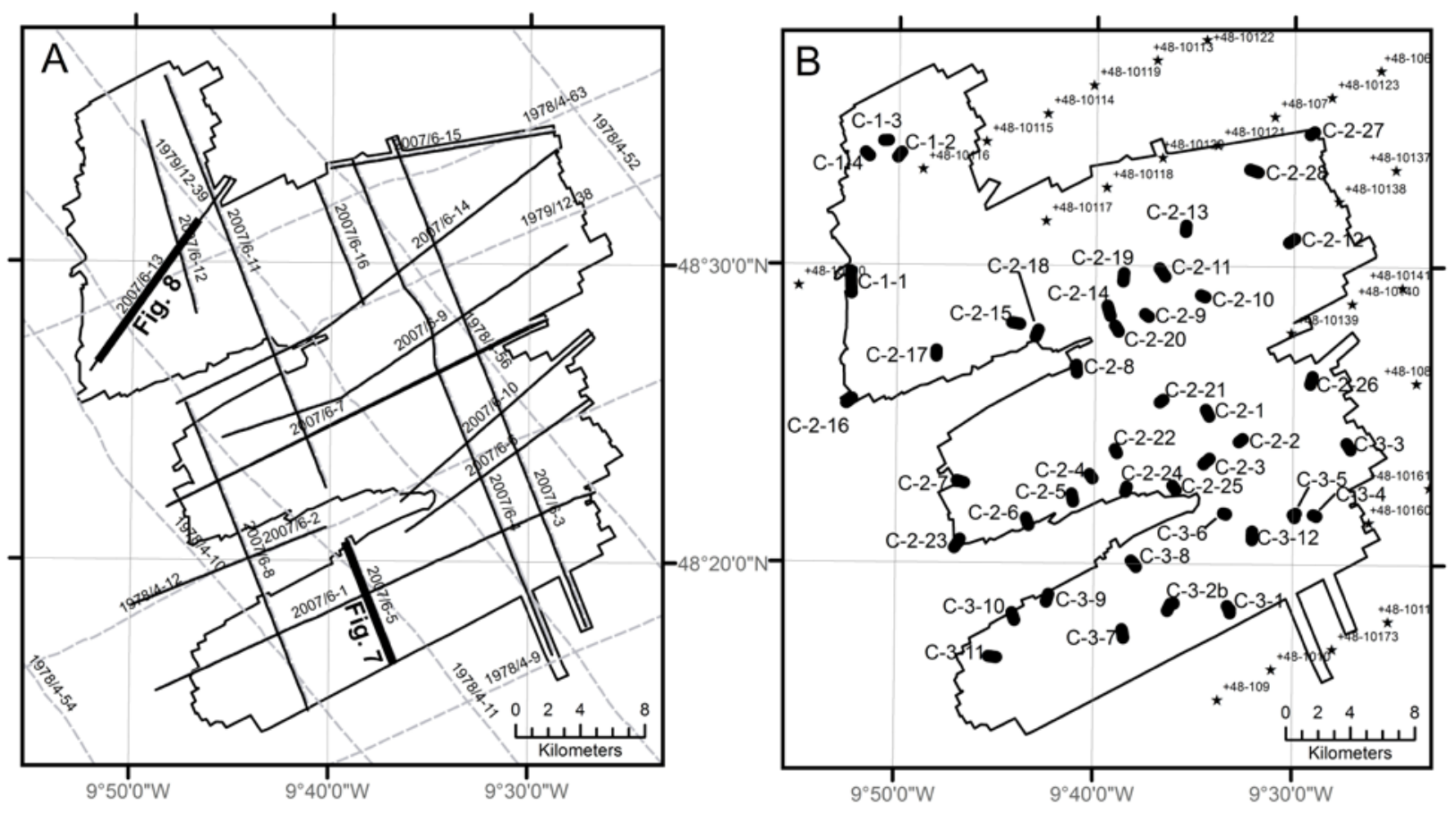

Fig. 3. A) Map showing the location of existing BGS seismic lines (dashed grey lines) and MESH cruise 01-07-01 seismic data (black lines). B) Map showing the location of existing BGS samples (black stars) with their corresponding sample number (for example +48-10 137) and MESH cruise 01-07-01 camera transects with their corresponding number (for example C-2-17). 


\section{Results}

\subsection{Geomorphology and sedimentology}

The multibeam bathymetry data show that the Dangeard Canyon trends east north-east and the Explorer Canyon trends north-east (Fig. 1). Interfluves, defined as areas of un-dissected, relict continental shelf, are located between these canyons ( $\underline{\text { Fig. } 1}$ ) and are typified by slope angles of $<3^{\circ}$ down to a water depth of 400-450 $\mathrm{m}$. Slope angles increase to $>20^{\circ}$ within the canyon heads and areas of mass wasting on the canyon flanks. Slope angles of between $10^{\circ}$ and $20^{\circ}$ are present on sections of smooth, north facing, canyon flanks.

Dangeard Canyon comprises two main incisions, each with a network of tributary gullies, and feeding into the main canyon (Fig. 1). A well developed, $4.5 \mathrm{~km}$ diameter, 'cauliflower' shaped amphitheatre rim feature is present at the shelf break, at the source of the southerly gully (Fig. 1). The presence of such features suggests that headward erosion evolved in the direction of the continental shelf and turbidity currents generated down slope are likely to be responsible for the erosional features observed. The uppermost section of the northerly gully comprises a 700-900 m wide, u-shaped, smooth gully bottom with slope angles of $<1.5^{\circ}$ (Fig. 1). Approximately $4.5 \mathrm{~km}$ before merging with the main canyon, the gully assumes a more typical physiography, narrowing and becoming more deeply incised with increased slope angles. It is currently unclear as to the evolution of the flat, upper reaches of this gully. Numerous headwall scars from slumps and slope failures are present on the northern flank of Dangeard Canyon while they are conspicuous by their absence on the southern flank (Fig. 1). The process of slope failure along the main canyon flanks creates gravity driven flows, gradually widening the canyon by retrogressive canyon wall failure (Cunningham et al., 2005).

Explorer Canyon is fed by a number of gullies (Fig. 1). A number of amphitheatre rims are observed on the upper walls of the northern canyon flank and in the canyon head (Fig. 1). Similar to Dangeard Canyon, the southern flank of Explorer Canyon exhibits fewer topographic features and is largely smooth and featureless with occasional indications of mass-wasting evident (Fig. 1). The northern flanks of both canyons host fluted features comprising a complicated gully network that interplay with the mass-wasting scars (ig. 1).

Two main types of bedforms were observed in the study area. (i) The outer continental shelf (water depths $<200 \mathrm{~m}$ ) hosts a number of major sandwave fields (Fig. 1 and Fig. 4). The crests of at least 5 sandwaves up to $7 \mathrm{~m}$ in height above the surrounding sea floor are imaged within a kilometre of the head of Explorer Canyon (Fig. 1 and Fig. 4). The sandwaves are oriented northwest-southeast and comprise very fine, sandy sea-bed sediment as ground-truthed by camera transect C-2-27 and nearby BGS sea-bed samples (Figs. $3 \mathrm{~b}$ and 4). Wavelengths of up to $350 \mathrm{~m}$ were observed (Fig. 4B) and both the seismic data and multibeam bathymetry data show the sandwaves are asymmetric (Fig. 4B). (ii) Sediment ripples with wavelengths commonly 5-10 cm, occasionally up to $30 \mathrm{~cm}$, were frequently observed throughout the study area.

The distribution of sea-bed sediments (Fig. 5 ) within the canyons has been interpreted from BGS sieved and analysed sea-bed samples and shallow cores ( 25 grab samples and 8 vibrocore samples all located on the outer continental shelf (Fig. 3b)), sea-bed photographs (ㅌig. 3 b) and multibeam echosounder data (Fig. 1 and Fig. 2). Evans (1990) reports that overall the sea-bed sediments of the outer continental shelf are up to $1 \mathrm{~m}$ in thickness overlying a lag deposit of gravelly sand. Analyses of BGS grab samples from the outer continental shelf report that the sediments are rich in bioclastic debris with foraminifera forming the main component of bioclastic debris along the outer continental shelf (Evans, 1990). 

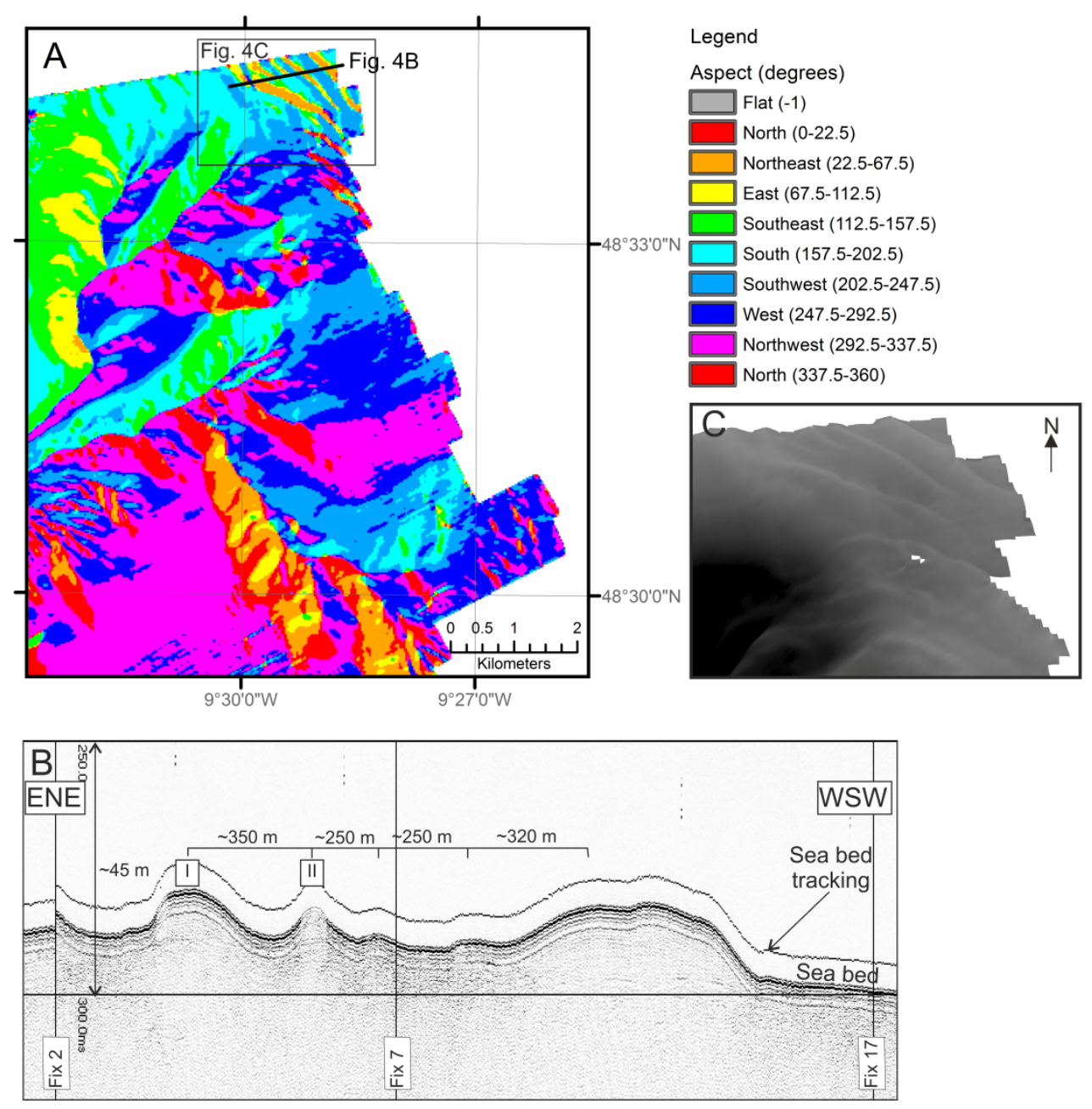

Fig. 4. A) Map showing the aspect of the sea bed over the two sandwave areas (for location see Fig. 1) derived from the multibeam bathymetry data. B) Part of deep-tow boomer profile 2007/06/15 crossing the sandwaves. Sandwave ' $I$ ' is 7 $\mathrm{m}$ in height and ' $\mathrm{Il}$ ' is $3 \mathrm{~m}$ in height above the surrounding sea floor. Wavelengths between 5 of the sandwaves are shown (e.g. $\sim 350 \mathrm{~m}$ ). For location see (A). C) 3D shaded relief image showing a perspective view of sandwaves located at the head of Explorer Canyon. For location see $(A)$.

Sand and mixed substrata were observed on the outer continental shelf, in the canyon heads, and on the canyon flanks in water depths $<500 \mathrm{~m}$ although isolated areas of mixed substrata were observed on the Dangeard Canyon floor and patches of sand were observed on both the Dangeard and Explorer canyon floors (Fig. 5). This was most likely as a result of transport down the canyon heads and along-slope transport by contour currents. Areas of biogenic gravel comprising coral and shell fragments in the form of rubble derived locally from a number of mini-mounds (see below) cover the tops of the canyon interfluves between water depths of $250 \mathrm{~m}$ and $410 \mathrm{~m}$ ( $\underline{\text { Fig. }}$ ). The presence of biogenic gravels is not limited to the interfluves. Mapped areas of mixed substrata (Fig. 5) located between $200 \mathrm{~m}$ and $500 \mathrm{~m}$ water depth comprise both lithic and biogenic sand and gravel. Predominantly mud and sandy muds (ig. 5 ) were observed in water depths $>500 \mathrm{~m}$ which is in agreement with other studies from the region (Cunningham et al., 2005, Evans, $\underline{1990}$ and Evans and Hughes, 1984). 


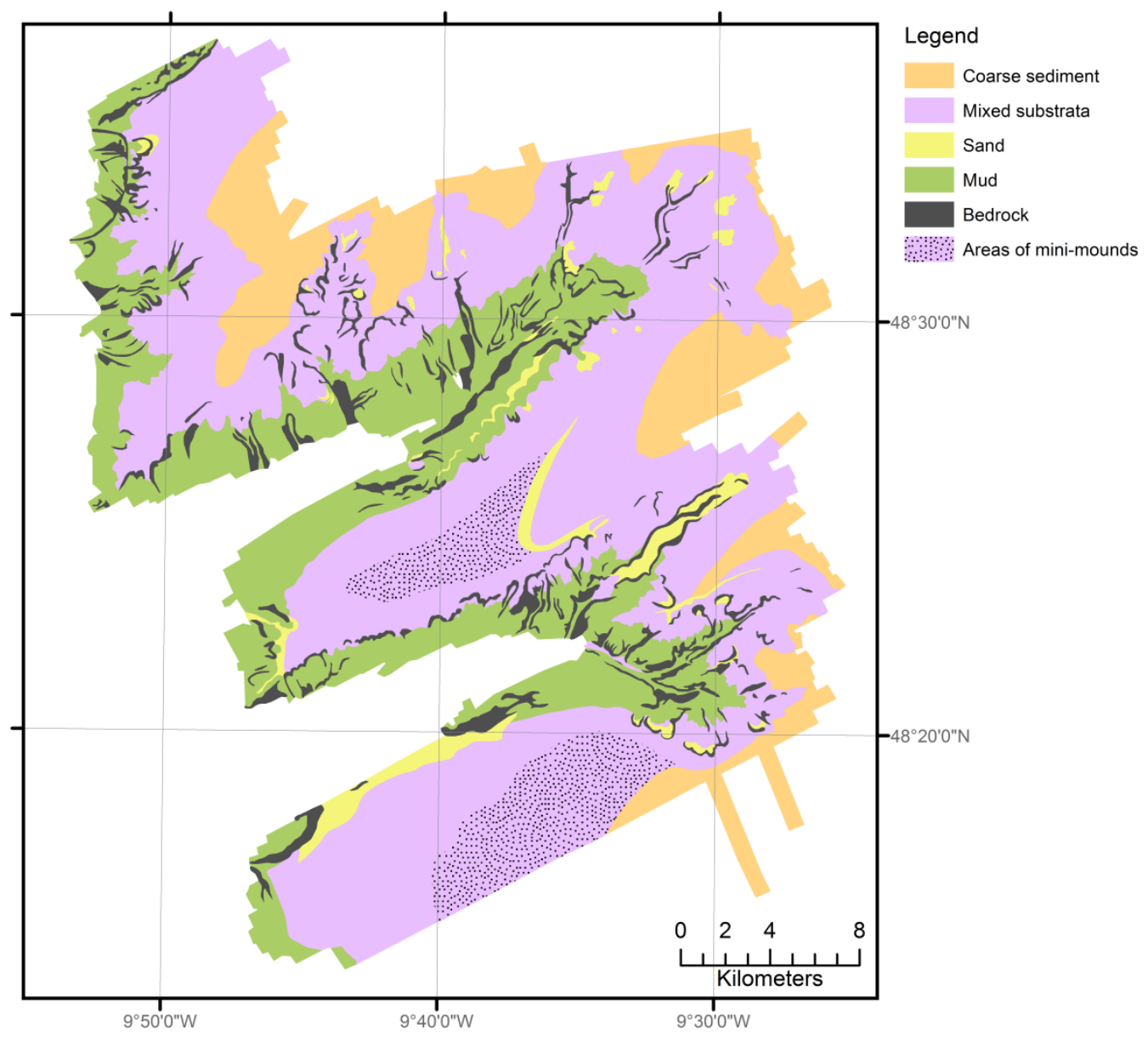

Fig. 5. Interpretation of sea-bed sediments based on integration of the multibeam echosounder data and groundtruthing sites within the study area.

Areas of rock cropping out at sea bed were observed in areas with slope angles $>20^{\circ}$ and only found in water depths $>300 \mathrm{~m}$ corresponding to amphitheatre rims, slump headwalls and flute features located on the canyon flanks (Fig. 1 and Fig. 5). Rock was not observed, or interpreted to be present, in areas of smooth canyon flanks with comparable slope angles such as on the north north-westerly facing southern flanks of the Explorer and Dangeard Canyons (Fig. 5).

The range of backscatter intensity data (Fig. 2) observed over the study area reflects the distribution of seabed sediments. Low backscatter values, indicated by areas of pale grey, are observed on the outer continental shelf down to water depths of around $250 \mathrm{~m}$ (Fig. 2). This is coincident with areas of smooth, relatively flat sea bed with slope angles generally $<2^{\circ}$ comprising sea-bed sediments such as sand and muddy sand (Fig. 5). Areas of high backscatter intensity, indicated by areas of dark grey to black, are observed in areas of coarser sediments such as mixed substrata, with cobbles and boulders observed on camera data. Areas of the highest backscatter intensity correspond to areas of rock cropping out at sea bed (Fig. 2 and Fig. 5). Areas of mottled lighter and darker patches of backscatter intensity located on the outer continental shelf and tributary gullies (Figs. 2 and $\underline{6} B$ and $E$ ) are coincident with areas of spotting in fine scale BPI ( $\underline{\text { Fig. }} 6 \mathrm{C}$ and F), suggesting the presence of small mounded features. 

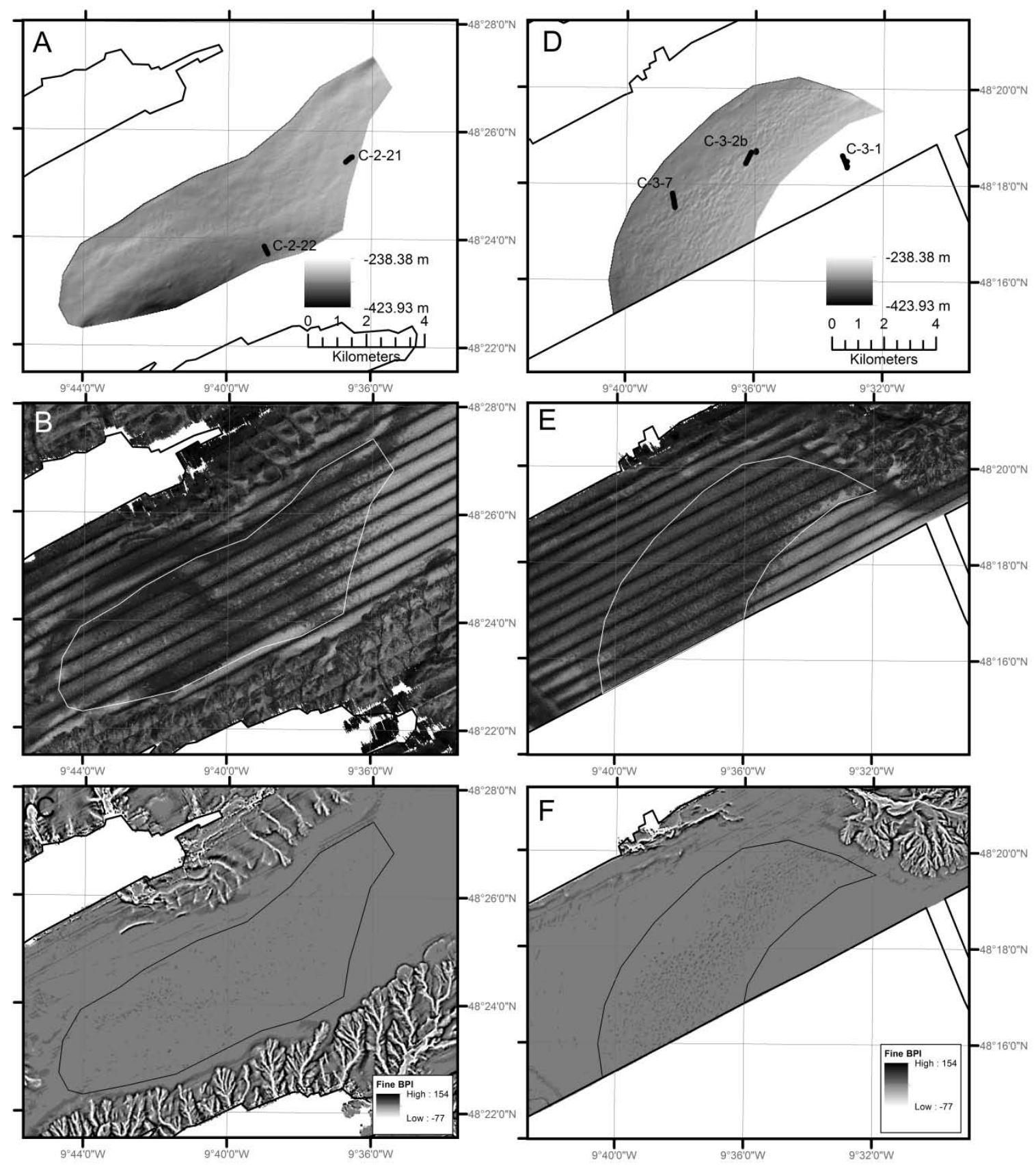

Fig. 6. A) Detail of El showing shaded relief map of multibeam bathymetry data (outline shown in B and C) and the location of camera transects over the Explorer CWC mini-mound province. B) Detail of El showing mottled backscatter intensity response over the Explorer CWC mini-mound province. C) Detail of El showing spotted fine scale BPI variation over the Explorer CWC mini-mound province. D) Detail of DI showing shaded relief map of multibeam bathymetry data (outline shown in E and F) and the location of camera transects over the Dangeard CWC mini-mound province. E) Detail of DI showing mottled backscatter intensity response over the Dangeard CWC mini-mound province. F) Detail of DI showing spotted fine scale BPI variation over the Dangeard CWC mini-mound province. For location see Fig. 1 and 2.

More than 400 'mini-mound' features were identified on the interfluves between Dangeard and Explorer canyons located in water depths of between $250 \mathrm{~m}$ and $410 \mathrm{~m}$ (Fig. 6). Topographic profiles across a number of the features indicate that the mini-mounds are up to $3 \mathrm{~m}$ in height above the surrounding sea floor and have base diameters of between $50 \mathrm{~m}$ and $150 \mathrm{~m}$. Fewer mini-mounds were observed on the Explorer Canyon interfluve, where around $\mathbf{3 0}$ mounds have been identified, compared to the Dangeard Canyon 
interfluve, where between 350 and 400 mounds have been identified. Mini-mounds were absent from the interfluves between Explorer Canyon and the canyon located in Irish waters (ig. 1).

The mounds appear as mottled areas of strong reflectance on maps of backscatter intensity (Fig. $6 \mathrm{~B}$ and E) with maps of BPI (Fig. $6 \mathrm{C}$ and F) being the most effective at identifying individual mounds and chains of mounds. The flanks of individual mounds have a slope angle generally $<4^{\circ}$ in the Explorer province and $<7^{\circ}$ in the Dangeard province.

Seismic data show that these mounds are surficial features with no sub-surface expression, nor are similar morphological shapes seen in the shallow section (Fig. 7).

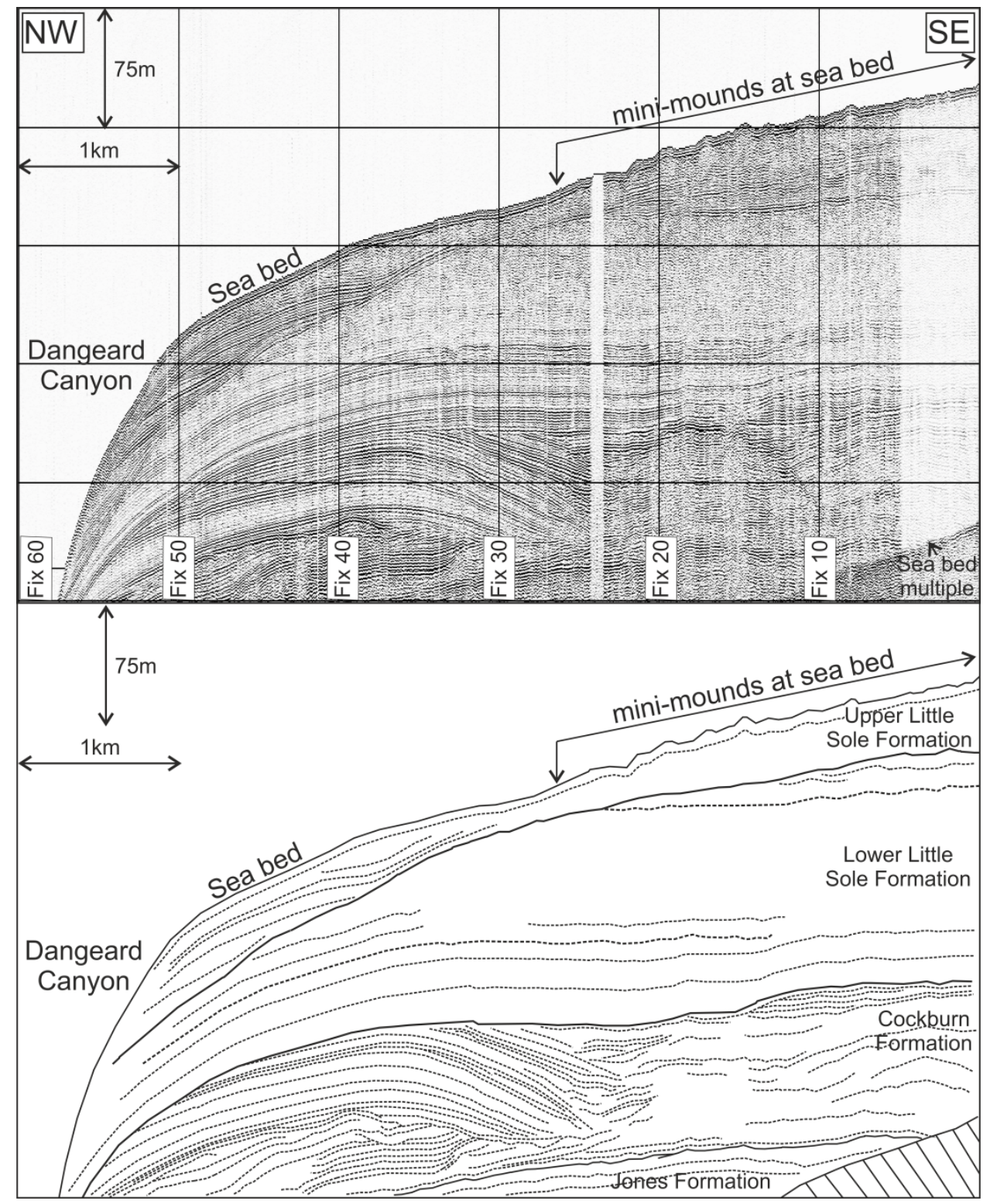

Fig. 7. Sparker profile 2007/06/05 demonstrating the sea-bed expression of CWC mini-mounds of the Dangeard minimound province and interpreted Neogene formations. For location see Fig. 1 and 3a. 


\subsection{Sub-surface geology}

Three Neogene formations mapped regionally (Evans, 1984 and Evans, 1990) have been identified within the study area and will be discussed here along with their relationship to the seismic interpretation described (Table 1; Fig. 7).

Table 1. Relationship between seismic units interpreted in this study and established Neogene formations from the geographic area.

\begin{tabular}{|c|c|c|c|c|}
\hline $\begin{array}{l}\text { Seismic } \\
\text { unit }\end{array}$ & Seismic characteristics & $\begin{array}{l}\text { Corresponding } \\
\text { Neogene formation }\end{array}$ & Age & $\begin{array}{l}\text { Sedimentary } \\
\text { characteristics }\end{array}$ \\
\hline Unit I & $\begin{array}{l}\text { Discontinuous unit } \\
\text { comprising slump } \\
\text { deposits and infilled } \\
\text { palaeovalleys. }\end{array}$ & $\begin{array}{l}\text { Upper Little Sole } \\
\text { Formation }\end{array}$ & $\begin{array}{l}\text { Pliocene to } \\
\text { Pleistocene }\end{array}$ & \multirow{3}{*}{$\begin{array}{l}\text { Fluvial or shelfal } \\
\text { deposits. Only sample } \\
\text { recovered from the } \\
\text { Upper Little Sole } \\
\text { Formation was an olive- } \\
\text { grey, clayey sand } \\
\text { deposited in water depth } \\
>50 \mathrm{~m} \text {. }\end{array}$} \\
\hline Unit II & $\begin{array}{l}\text { Sheet-like unit } \\
\text { comprising fewer } \\
\text { prograding units that } \\
\text { Unit III. }\end{array}$ & $\begin{array}{l}\text { Upper Little Sole } \\
\text { Formation }\end{array}$ & $\begin{array}{l}\text { Pliocene to } \\
\text { Pleistocene }\end{array}$ & \\
\hline Unit III & $\begin{array}{l}\text { Characterised by buried } \\
\text { canyons and sigmoidal } \\
\text { reflectors. Completely } \\
\text { absent in areas of } \\
\text { pronounced incision. } \\
\text { Below a water depth of } \\
\text { around } 300 \text { m generally } \\
\text { more parallel reflectors } \\
\text { are present. }\end{array}$ & $\begin{array}{l}\text { Lower Little Sole } \\
\text { Formation }\end{array}$ & $\begin{array}{l}\text { Pliocene to } \\
\text { Pleistocene }\end{array}$ & \\
\hline Unit IV & $\begin{array}{l}\text { Erosion surface at base } \\
\text { of unit. Reflectors } \\
\text { downlap onto Unit V. }\end{array}$ & Cockburn Formation & $\begin{array}{l}\text { Mid- to late } \\
\text { Miocene }\end{array}$ & $\begin{array}{l}\text { Deltaic sequence of } \\
\text { calcarenites. }\end{array}$ \\
\hline Unit V & $\begin{array}{l}\text { Reasonably parallel, } \\
\text { continuous reflectors. }\end{array}$ & Jones Formation & $\begin{array}{l}\text { Early to } \\
\text { mid- } \\
\text { Miocene }\end{array}$ & $\begin{array}{l}\text { Progradational } \\
\text { calcilutites. }\end{array}$ \\
\hline
\end{tabular}

\subsubsection{Unit V (Jones Formation)}

The main seismic characteristic of Unit $\mathrm{V}$ are the reasonably parallel, continuous reflectors with several prominent reflectors located at the top of the unit (Fig. 7). Over the crests of the interfluves the top of the Jones Formation lies approximately $250 \mathrm{~m}$ below sea bed (ig. 7).

Unit $\mathrm{V}$ is correlated with the early to mid-Miocene age Jones Formation that comprises progradational calcilutites with up to $25 \%$ sand-sized particles (Evans and Hughes, 1984). The Jones Formation rests unconformably on Paleogene strata in the vicinity of the study area. This formation was deposited on a shelf with slightly deeper water depths than present day, with relatively uniform rates of deposition and low energy sea-bed currents (Evans and Hughes, 1984). 


\subsubsection{Unit IV (Cockburn Formation)}

A characteristic of Unit IV is the erosion surface which marks the base of this sediment package in the vicinity of the outer continental shelf and upper continental slope (Fig. 7). The reflectors of Unit IV downlap onto the

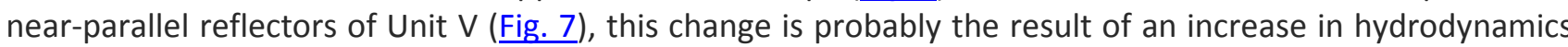
as discussed above. Evans and Hughes (1984) report that the Cockburn Formation has a thickness in excess of $150 \mathrm{~m}$ in the vicinity of the shelf break.

The Cockburn Formation of mid- to late Miocene age comprises a deltaic sequence of calcarenites with predominantly fine sand-sized particles (Evans and Hughes, 1984). The Cockburn Formation represents an increase in the power of the hydraulic regime of the Celtic Margin suggested to be a result of increasing sea levels due to a connection made between the southern North Sea and the SW Approaches at this time (Evans, 1990). The unconformable relationship between this formation and the overlying Little Sole Formation suggests that the top of the Cockburn Formation was located at the limit of wave influenced sediment mobilisation during Pliocene times.

\subsubsection{Unit I-III (Little Sole Formation)}

The Little Sole Formation was originally subdivided into the Upper and Lower members by Evans (1990); however, where possible, it is informally divided into three units in this study (Table 1). Unit I comprises a discontinuous slump and palaeovalley infill deposit (Fig. 7). Unit II comprises a sheet-like deposit, 50-60 m in thickness, which rests unconformably on the peneplaned Cockburn Formation (Fig. 7). Unit III is a discontinuous wedge-shaped member only found on the continental slope (Fig. 7). It is suggested here that a number of buried paleovalleys are present within Unit III which have subsequently been re-excavated during Pleistocene times (Fig. 8). Unit III is up to $300 \mathrm{~m}$ in thickness and is absent in areas of pronounced incision, such as much of the outer continental shelf, but is preserved on the smooth canyon interfluves (Fig. 7). Sigmoidal reflectors which may represent buried sandwaves or contourite deposits are also a characteristic of Unit III.

\subsection{Observations of canyon mega-fauna}

A total of 874 images were quantitatively analysed with 161 morphospecies identified and catalogued. Full analyses of these data are presented in Davies et al. (this issue) and thus only qualitative observations will be presented here.

The upper part of the canyon system on the continental shelf is characterised by soft sediments with both surface dwelling and burrowing ophiuroids. Moving further into the canyon system, the interfluve areas are characterised by squat lobsters (Munida), ophiuroids and crinoids (Leptometra celtica) on mixed substratum comprising both lithic and biogenic sand and gravel (Figs. 9 and $\underline{10 B}$ ). Two areas of mini-mounds interrupt this relatively flat topography associated with the canyon interfluves with the summit of the mounds playing host to coral rubble associated fauna including ophiuroids and squat lobsters (Munida) (Davies et al., this

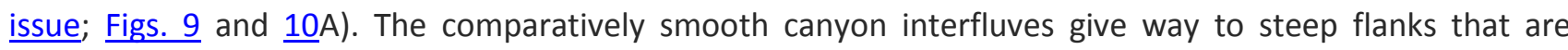
characterised by sea pens and burrowing anemones (Kophobelemnon stelliferum and Cerianthidae including Pachycerianthus). Lophelia pertusa colonies were observed on distinct flute-like features.

Whilst an intact CWC reef was not observed on the interfluve areas of the canyons, coral rubble was clearly associated with the mini-mound features (Figs. 9 and $\underline{10} \mathrm{~A}$ ). Individual mounds are characterised by coral fragments in the form of rubble or biogenic gravel (Fig. 10A) and were coincident with areas of high BPI on the interfluves of the canyons ( $\underline{\text { Fig. } 9 \mathrm{~b}}$ and c). The extent of coverage of rubble and the associated species suggested that this assemblage was not typical 'rubble apron' associated with live reef areas, but was once an area that hosted live Lophelia pertusa colonies that have been damaged, most probably by fishing 
activity, which is known to be intensive in this area (CEFAS, personal communications). Anthropogenic debris associated with fishing activity was observed in a third of video transects (Stewart and Davies, 2007).
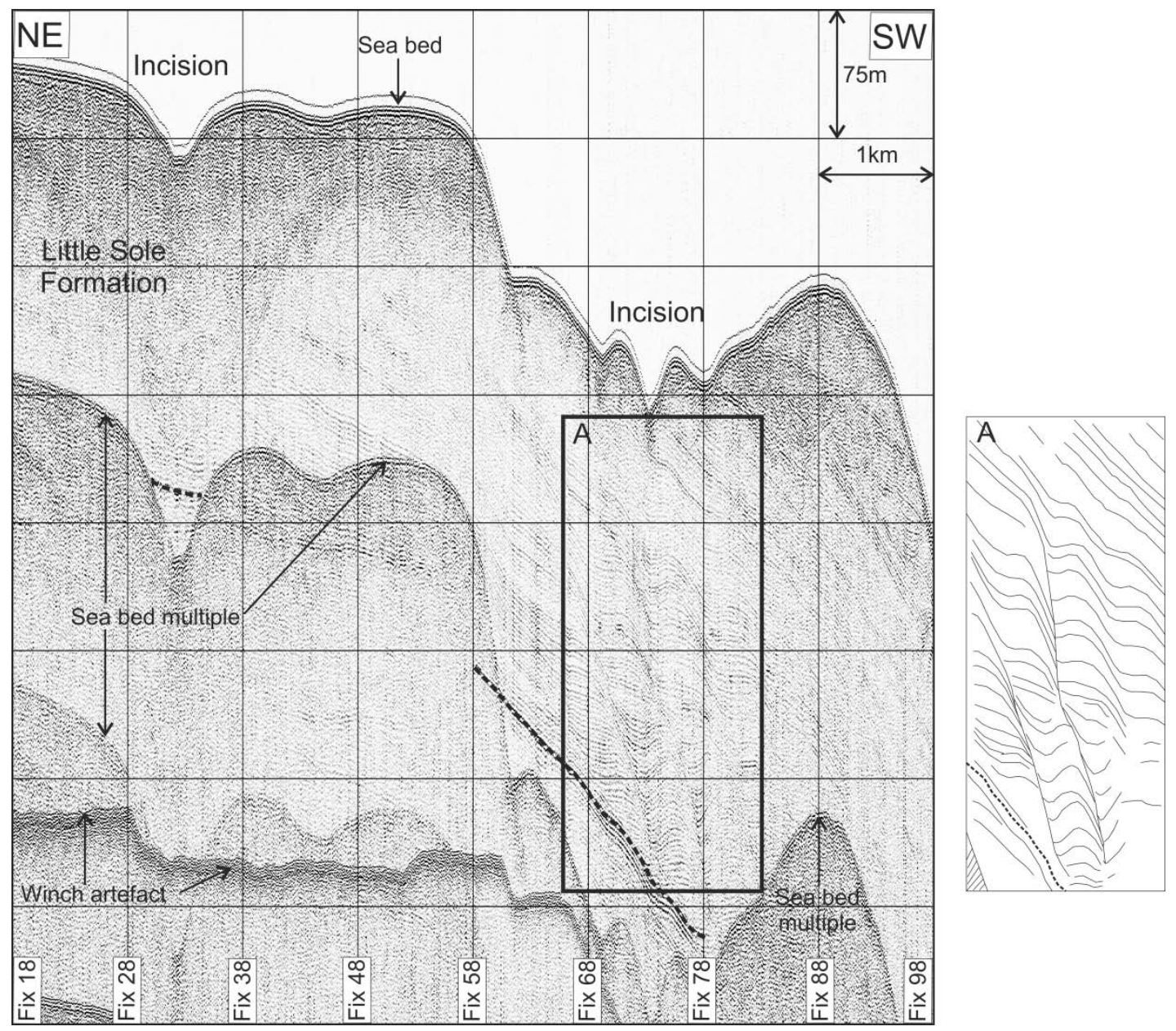

Fig. 8. Sparker profile 2007/06/13 showing the presence of sigmoidal reflectors indicating a nested suite of buried palaeovalleys (box A) within the Lower Little Sole Formation. The dashed line marks the base of the Little Sole Formation. For location see Fig. 1 and 3a. 

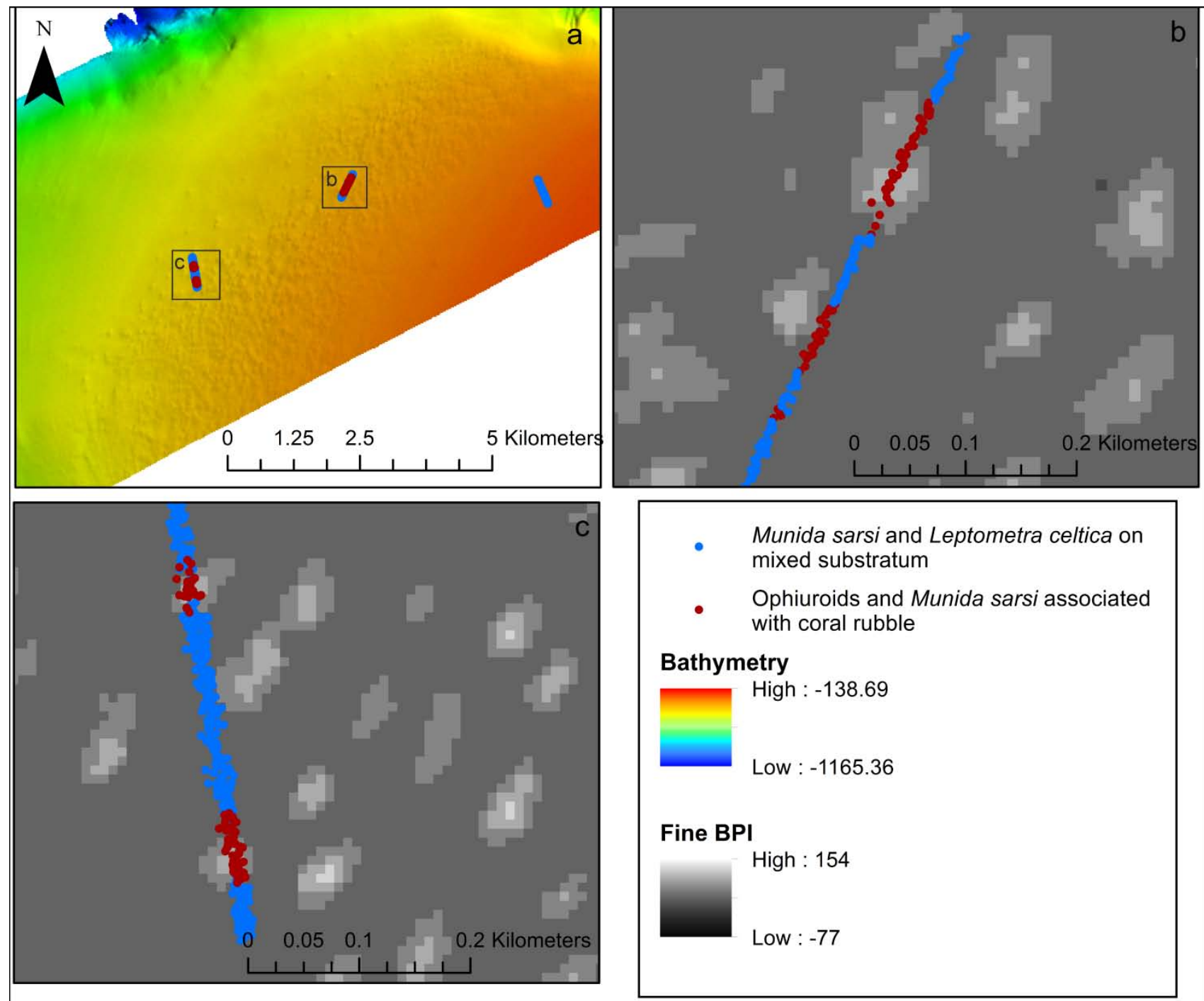

Fig. 9. Distribution of observed fauna from the Dangeard CWC mini-mound province as seen in camera transects $C-3-2 b$ (b) and C-3-7 (c) (Davies 2012). (a) Overview of multibeam bathymetry and camera data acquired over the Dangeard CWC mini-mound province. For location see Fig. 1. (b) and (c) The change in observed fauna mapped from video footage, for location see (a). Areas of high fine scale BPI correspond to individual mounds. 

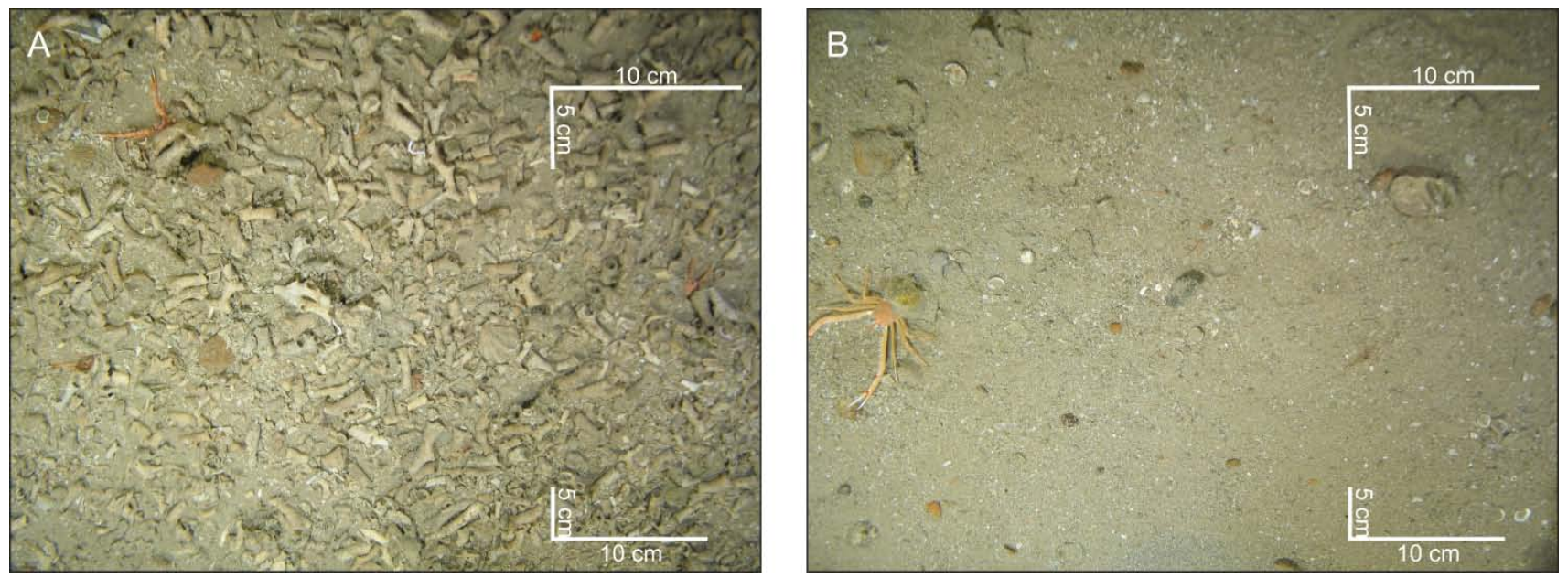

Fig. 10. A) Example photograph of coral rubble associated fauna (including squat lobsters (Munida) and ophiuroids) representing on-mound observed fauna. B) Example photograph of between-mound associated fauna (characterised by squat lobsters (Munida), ophiuroids and crinoids (Leptometra celtica) on mixed substratum.

\section{Discussion}

\subsection{Canyon evolution}

The morphology of the Celtic continental slope is characterised by a series of spurs and canyons organised into submarine drainage basins. This study has focussed on the heads of the Explorer and Dangeard canyons, which feed the larger Whittard Canyon and subsequently the Celtic Deep-Sea Fan. This study has shown that both these canyons are characterised by gullies and numerous tributaries incising the upper slope and outer continental shelf between $180 \mathrm{~m}$ and $400 \mathrm{~m}$ water depth (Fig. 1). The shelf break of the Celtic Margin is unusually deep resulting from prolonged subsidence of this passive margin (Pantin and Evans, 1984). The position of the shelf break is not always easily defined firstly due to the gentle transition on the interfluves and secondly due to headward erosion of the canyon back walls and incision of smaller v-shaped canyons in Pleistocene times in response to episodic, sea level lowstands (i․ 1 and Fig. 8).

The importance of shelf-wide glaciations for the turbidite systems of the Celtic and Armorican Margins is significant. Gentle undulations in the sea bed palaeo-topography would have been greatest above buried palaeovalleys (Evans, 1990). This would have caused erosive density and turbidity currents flowing over the shelfbreak to gravitate into these depressions causing incision above the sites of previous incisions, producing a nested suite of palaeovalleys (Fig. 8). Previous studies have linked increased turbidity current activity with meltwater releases from ice sheets and associated relative sea-level lowstands (Scourse et al., $\underline{2009}$, Toucanne et al., 2008, Zaragosi, 2001 and Zaragosi et al., 2006).

The prevalence of mass wasting is primarily identified from headwall scars left by slumps and amphitheatre rim features (Fig. 1). High slope angles $\left(>20^{\circ}\right)$ coincident with amphitheatre rims, slump headwalls and flute features suggest that retrogressive erosion was taking place and is comparable to active areas of mass wasting documented in, for example, Ascension Canyon, Monterey Bay, USA (Greene et al., 2002). Processes causing mass wasting include oversteepening of canyon walls and drainage basins, and undercutting of canyon walls by turbidity currents causing instability and subsequently slope failure (Greene et al., 2002 and Lo lacono et al., 2011). De Mol et al. (2011) report the preferential erosion of the western flanks of Penmarc'h and Guilvinec canyons (Bay of Biscay) as evident by numerous gullies and flutes, while the eastern flanks are draped with soft sediment. The same pattern is described for the Dangeard and Explorer canyons (ig. 1). At Penmarc'h and Guilvinec canyons this morphology is attributed to strong E-W flowing 
bottom currents (De Mol et al., 2011) and it is suggested that the northerly flowing bottom currents in the vicinity of Dangeard and Explorer canyons are the cause of the comparable morphology (ig. 1).

This study describes two small areas of sandwaves (Fig. 1 and Fig. 4) with heights of up to $7 \mathrm{~m}$ above the surrounding sea floor. The sandwaves imaged by these data show that wavelengths are up to $350 \mathrm{~m}$ and show asymmetry (Fig. 4B). Other studies have proved the sandwave field extends eastwards along the outer continental shelf ( $\underline{\text { Cunningham et al., } 2005}$ and Evans, 1985) and up to $36 \mathrm{~km}$ shoreward (Evans, 1985).

Large, linear tidal sand ridges located in the Celtic Sea, which extend from the shelf-break towards the northeast, are suggested to be the source of sediment for these shelf-edge sandwave fields (Cunningham et $\underline{\text { al., } 2005}$ and Scourse et al., 2009). These ridges cover an area of ca. $65,000 \mathrm{~km}^{2},<200 \mathrm{~km}$ in length, $55 \mathrm{~m}$ high and $15 \mathrm{~km}$ wide (Reynaud et al., 1999 and Scourse et al., 2009) and are moribund tidally remobilised sediments representing the sedimentary bodies formed during the transgressive systems tract (Scourse et al., 2009). The source of the sediments forming the ridges is suggested as being from two outer shelf depocentres: (1) the Fleuve Manche on the south-eastern shelf, and (2) the Irish Sea Ice Stream shelf fan in the central-northern area (Scourse et al., 2009).

The proximity of the Explorer and Dangeard canyon heads to the shelf-edge sandwave fields and the Celtic Sea linear tidal sand ridges indicate that these canyon heads may provide a conduit for transporting sediment onto the slope (Cronin et al., 2005, Cunningham et al., 2005, Evans, 1990 and Scourse et al., 2009) and to the deeper drainage basins. The evolution of a u-shaped, smooth bottomed gully located in the Dangeard Canyon head (ig. 1) is unclear although possible theories include a hanging valley scenario, infilling of a gully by material slumped from the canyon flanks, or sediment transported into the gully from those shelf-edge sandwaves.

The movement of sediments both up- and down-canyon by low energy, tide initiated hydrodynamic events (De Stigter et al., 2007, De Stigter et al., 2011, Huvenne et al., 2011 and Mulder et al., 2012) also has a significant influence on modern sediment transport. Mulder et al. (2012) describe permanent currents that alternate periodically between a down canyon and up canyon motion, the intensity of which are more correlated to internal tides rather than surface tides. The Bay of Biscay is one of the areas with the strongest internal tides in the world (e.g. Jézéquel et al., 2002 and Pingree et al., 1986) therefore it can be suggested that the influence of internal tides may be significant in the Explorer and Dangeard canyons although longterm current meter observations would need to be acquired to confirm this.

\subsection{Canyon and mini-mound fauna}

The fauna observed associated within the canyons studied here (see also Davies et al., this issue) have also been observed in the neighbouring Whittard Canyon (Huvenne et al., 2011, Morris, 2011 and Morris et al., 2013) and other European canyon systems (Cartes et al., 2009 and Gori et al., 2013). In general the observed fauna are also known from the wider area incorporating the Rockall Trough and neighbouring banks and seamounts, Porcupine Bank and Seabight (Bullimore et al., 2013, Howell et al., 2010a, Howell et al., 2010b, Narayanaswamy et al., 2013 and Tyler and Zibrowius, 1992) and could not be considered to be unique to these canyon features. Many of the species identified by Tyler and Zibrowius (1992) inhabiting the rocky deep western escarpments of the neighbouring Porcupine Bank and Goban Spur were observed in the present study, suggesting little difference in the megafaunal communities of the canyon and neighbouring continental slope (where comparable substratum types and environmental conditions are present).

The association between mound features and Lophelia pertusa occurrence is well established ( $\mathrm{De}$ Mol et al., 2002, Henry and Roberts, 2007 and Roberts et al., 2003). Optimal environmental conditions (predominantly water temperature, current strength, sediment supply, food availability and hard substrate) favour coral settlement and growth. From previous studies it is known that these optimum conditions are often linked to 
water mass boundaries (Dullo et al., 2008). The CWC mini-mounds described in the present study, with which the Lophelia pertusa rubble was associated, are similar in size to the Macnas mounds in the Porcupine Seabight, which are between 50 and $100 \mathrm{~m}$ in diameter and $5 \mathrm{~m}$ high and found at water depths of 300-500 $\mathrm{m}$ (Wilson et al., 2007); the Darwin mounds in the Rockall Trough, which are typically $75 \mathrm{~m}$ in diameter and 5 $\mathrm{m}$ high and found at water depths of $1000 \mathrm{~m}$ (Masson et al., 2003); and the Moira Mounds in the Porcupine Seabight, which are between 20 and $35 \mathrm{~m}$ in diameter and between 3 and $11 \mathrm{~m}$ high and found at water depths of 800-1100 m (Wheeler et al., 2011). Mini-mounds with associated Lophelia pertusa rubble have also been reported on the interfluve (Odet Spur) of the Guilvinec Canyon (Bay of Biscay), being up to $5 \mathrm{~m}$ high and found at water depths of 260-350 m (De Mol et al., 2011).

The Dangeard and Explorer CWC mini-mound provinces, the Macnas mounds and mounds located on the Odet Spur are all located in shallow water depths $(<500 \mathrm{~m})$ above the interface between the ENAW and the MOW. De Stigter et al. (2007) report that the mixing of these water masses results in enhanced suspended material and elevated bottom current velocities which would favour CWC feeding and growth. The Moira and Darwin mounds by comparison are live CWC mounds located in areas of elevated bottom current velocities (Huvenne et al., 2009b and Wheeler et al., 2011) in water depths $>800 \mathrm{~m}$. The Darwin mounds for example comprise numerous, small sea-bed mounds (Huvenne et al., 2009b and Masson et al., 2003), that have the CWC Lophelia pertusa associated with them, while the 'tails' of the mounds support dense populations of the xenophyophore Syringammina fragilissima. No 'tails' are associated with the CWC minimounds identified during the course of this study.

The CWC mini-mounds described in the present study lack evidence of successive mound accumulation within the shallow sub-surface, this is comparable to the Moira mounds that also have little sub-surface expression and have no evidence of successive reef formation (Wheeler et al., 2011). Therefore we can conclude that the CWC mini-mounds of the Dangeard and Explorer provinces are, in geological terms, relatively young and possibly Holocene in age formed by colonisation and growth on a relict sea bed rather than accumulation through time. Wheeler et al. (2011) propose that the process of merging of individual mounds and clusters of mounds through continued growth may result in the formation of coral carbonate mounds, thus like the Moira Mounds which may represent an early growth phase for carbonate mounds, the mini-mounds of this study may represent a short-lived period of mound building. The process of accretion of these larger mounds is not well understood although coring through the Challenger Mound by IODP Expedition 307 revealed gradual reef stacking over the course of $2.6 \mathrm{Ma}$ but the record is discontinuous with glacially derived sediments often missing (

It is unknown at this point whether the CWC mini-mounds of the Dangeard and Explorer provinces are relict due to a change in environmental conditions and therefore unlikely to support new coral growth even if fishing pressure were to be removed, or if trawling damage is solely to blame for the coral rubble in the area. If conditions were right, it is possible that the mounds may return to a more active and healthy state if fishing pressure was removed as dead coral framework is believed to offer a suitable substrata for renewed growth (Roberts et al., 2006). New coral growth could increase mound elevation, which would enhance favourable environmental conditions for growth, allowing the corals to take advantage of nutrient rich oceanic currents for example, providing a positive feedback towards stimulating further coral colonisation and growth. For regrowth to occur an active larval supply to the area would be required. The predominant direction of the slope current is to the north-west (Pingree and Le Cann, 1989) suggesting larval supply should come from the south east. Live Lophelia pertusa reef formations have been reported from the neighbouring La Chapelle Bank (180-1000 m), and la Grande Vasière (180-1800 m) (Le Danois, 1948) suggesting regrowth may be possible if corals in these areas are still present. However, dating of CWC from the Penmarc'h and Guilvinec canyons using U-series revealed that CWC from the shallow (280-290 m water depth) setting were older $(7.4-9.1 \mathrm{ka})$ than those from the deeper $(700-920 \mathrm{~m})$ setting $(1.2-2.3 \mathrm{ka})$ suggesting a migration of the CWC habitat into deeper water (De Mol et al., 2011). The cause of the 
migration is uncertain although De Mol et al. (2011) suggest changing sea level and rising temperatures may be a cause, forcing the CWC into deeper waters where favourable environmental conditions existed.

This study has shown that the derived layer of BPI was the most useful for identifying the presence of minimounds on both the Explorer and Dangeard interfluves, second to this were the maps of backscatter intensity data and slope. Mini-mounds were absent from the interfluve between Explorer Canyon and the canyon located in Irish territorial waters. However, there may be an indication of spotting in both the backscatter intensity and fine BPI between $\sim 250 \mathrm{~m}$ and $350 \mathrm{~m}$ water depth on this canyon but this zone was not ground-truthed.

The flanks of the mini-mounds have a slope angle generally $<4^{\circ}$ in the Explorer province and $<7^{\circ}$ in the Dangeard province. This suggests that the Explorer mini-mound province has been subject to more reworking than Dangeard possibly as a result of intensive fishing which is known to have occurred in this area (CEFAS, personal communications). Puig et al. (2012) report that sediment remobilisation and removal by bottom trawling have caused smoothing of sea floor morphology over time in La Fonera/Palamós Canyon (NW Mediterranean Sea). It is suggested here that bottom trawling may have had the same impact on the Dangeard and Explorer mini-mound provinces as documented by the variation in slope angle between the two provinces. In addition to the physical damage resulting from bottom trawling, as evidenced from the coral rubble observed on the interfluves, the long-term effects include the homogenisation of the sea bed, reduction in species diversity (Veale et al., 2000), and re-suspension of sediments (Jones, 1992, Martin et al., 2008, Pilskaln et al., 1998 and Thrush et al., 2001). Martin et al. (2008) document an increase in sediment accumulation rates within La Fonera/Palamós Canyon due to strong sea floor disturbances caused by the local fishing fleet in the last decades. This has induced frequent gravity flows into the canyon, increasing down canyon sediment transport (Martin et al., 2008, Martin et al., this issue and Puig et al., 2012).

Measurements of near-bed (within $3 \mathrm{~m}$ of the sea bed) currents with direct relevance to sediment transport of re-suspended material are scarce. Therefore the development of a hydrodynamic model within the Explorer and Dangeard canyons would help clarify whether the canyon heads deflect along-slope currents, to cement the relationship between bottom currents and canyon flank morphology, to determine the frequency of turbidity currents and the influence of internal tides. An improved understanding of the sedimentary processes is crucial in determining whether retrogressive headward erosion could be ongoing today and determining where active along slope sedimentation is occurring.

\section{Conclusions}

Multibeam echosounder data and its derived layers of slope, rugosity and BPI have been combined with video ground-truthing data and 2D seismic data to provide a better understanding of the origin, evolution and biological assemblages of hitherto poorly investigated submarine canyons and mini-mounds of the SW Approaches.

The main conclusions are:

1. A number of sandwaves occur within $1 \mathrm{~km}$ of the head of Explorer Canyon. Large, linear tidal sand ridges located in the Celtic Sea are suggested to be the source of sediment for these shelf-edge sandwave fields.

2. Amphitheatre rims occur along the margins and heads of Explorer and Dangeard canyons and are interpreted as drainage basins indicative of retrogressive mass wasting in a shelfward direction.

3. The canyons are dominated by soft sediment assemblages and support species typical of the region at comparable depths and substrate types. 
4. More than 400 CWC 'mini-mound' features were identified on the Dangeard and Explorer canyon interfluves. They are located in water depths between $250 \mathrm{~m}$ and $410 \mathrm{~m}$, are up to $3 \mathrm{~m}$ in height, and between $50 \mathrm{~m}$ and $150 \mathrm{~m}$ in diameter. The flanks of individual mounds have a slope angle generally $<4^{\circ}$ in the Explorer province and $<7^{\circ}$ in the Dangeard province.

5. The mini-mounds are surficial features with no sub-surface expression suggesting they are, in geological terms, relatively young and possibly Holocene in age. Geological data suggest the minimounds are relict features and could be considered as examples of a short-lived, initial growth stage of mound development.

6. The mini-mounds were characterised by ophiuroids and Munida associated with Lophelia pertusa coral rubble.

7. It is unknown at this point whether the CWC mini-mounds would support coral regrowth if fishing pressure were to be removed.

The mini-mounds discovered as part of this study warrant further investigation. A programme of sampling these mounds may shed light on the age of these features, CWC reef formation and processes of mound accretion as well as providing information on past hydrodynamic activity on the margin between the Holocene and the Last Glacial Maximum. A future opportunity to investigate whether mini-mounds are also present on the interfluve located between Explorer and the Irish canyon in the 250-350 m zone identified from BPI and backscatter intensity would be cruicial in cementing the link between using BPI, backscatter intensity and slope as a proxy for identifying the location of these features.

\section{Acknowledgments}

This work has been supported by the British Geological Survey ongoing regional mapping programme (MAREMAP; www.maremap.ac.uk). The authors also wish to thank the captain, crew and scientific complement of the R/V Celtic Explorer for assistance in data collection during MESH Cruise 01-07-01, Joint copyright ${ }^{\circledR} 2007$ Defra, JNCC, Marine Institute, BGS, UoP. These data were recorded during a collaborative survey involving the Joint Nature Conservation Committee, the Marine Institute, the British Geological Survey and the University of Plymouth. The Department of the Environment, Fisheries and Rural Affairs (Defra) Natural Environmental Group Science Division (CRO 361) made a significant financial contribution to this work. This work contributes to the MESH project (www.searchmesh.net) that receives European Regional Development Funding through the INTERREG III B Community Initiative (www.nweurope.org). The authors wish to thank Prof. David Van Rooij and two anonymous reviewers for their comments which improved this manuscript. HAS publishes with permission of the Director, British Geological Survey (Natural Environment Research Council). The Joint Nature Conservation Committee supported JSD Ph.D. studies.

\section{References}

Bourillet, J.-F., Lericolais, G., 2003. Morphology and seismic stratigraphy of the manche palaeoriver system, western approaches. In: Mienert, J., Weaver, P., (Eds), European Margin Sediment Dynamics: Sides-scan Sonar and Seismic Images. Springer-Verlag, Berlin. 229-232.

Bourillet, J.-F., Reynaud, J.-Y., Baltzer, A., Zaragosi, S., 2003. The 'Fleuve Manche': the submarine sedimentary features from the outer shelf to the deep-sea fans. J. Quat. Sci. 18, 261-282.

Bourillet, J.-F., Zaragosi, S., Mulder, T., 2006. The French Atlantic margin and deep-sea submarine systems. Geo-Mar. Lett. 26, 311-315. 
Brodeur, R. D., 2001. Habitat-specific distribution of Pacific Ocean perch (Sebastes alutus) in Pribilof Canyon, Bering Sea. Cont. Shelf Res. 21, 207-224.

Bullimore, R.D., Foster, N.L., Howell, K.L., 2013. Coral-characterized benthic assemblages of the deep Northeast Atlantic: defining "Coral Gardens" to support future habitat mapping efforts. ICES J. Mar. Sci. 70, 511-522.

Canals, M., Puig, P., Durrieu de Madron, X., Heussner, S., Palanques, A., Fabres, J., 2006. Flushing submarine canyons. Nature. 444, 354-357.

Cartes, J.E., Maynou, F., Fanelli, E., Romano, C., Mamouridis, V., Papiol, V., 2009. The distribution of megabenthic, invertebrate epifauna in the Balearic Basin (western Mediterranean) between 400 and 2300 $\mathrm{m}$ : Environmental gradients influencing assemblages composition and biomass trends. J. Sea Res. 61, 244257.

Cronin, B.T., Akhmetzhanov, A.M., Mazzini, A., Akhmanov, G., Ivanov, M.K., Kenyon, N.H., Scientists, T.-S., 2005. Morphology, evolution and fill: Implications for sand and mud distribution in filling deep-water canyons and slope channel complexes. Sed. Geol. 179, 71-97.

Cunningham, M.J., Hodgson, S., Masson, D.G., Parson, L.M., 2005. An evaluation of along- and down-slope sediment transport processes between Goban Spur and Brenot Spur on the Celtic Margin of the Bay of Biscay. Sed. Geol. 179, 99-116.

Davies, J.S., 2012. Mapping deep-sea features in UK water for use in Marine Protected Area network design. Unpubl. PhD Thesis. Univ. Plymouth. 375pp.

Davies, J.S., Howell, K. L., Stewart, H.A., Guinan, J., Golding, N., 2013. Defining biological assemblages (biotopes) of conservation interest in the submarine canyons of the South West Approaches (offshore United Kingdom) for use in marine habitat mapping. Deep-Sea Res. II, Top. Stud. Oceanogr., this issue.

De Mol, B., Van Rensbergen, P., Pillen, S., Van Herreweghe, K., Van Rooij, D., McDonnell, A., Huvenne, V., Ivanov, V., Swennen, R., Henriet, J. P., 2002. Large deep-water coral banks in the Porcupine Basin, southwest of Ireland. Mar. Geol. 188, 193-231.

De Mol, L., Van Rooij, D., Pirlet, H., Greinert, J., Frank, N., Quemmerais, F., Henriet, J.-P., 2011. Cold-water coral habitats in the Penmarc'h and Guilvinec Canyons (Bay of Biscay): Deep-water versus shallow-water settings. Mar. Geol. 282, 40-52.

De Stigter, H.C., Boer, W., de Jesus Mendes, P.A., Jesus, C.C., Thomsen, L., van den Bergh, G.D., van Weering, T.C.E., 2007. Recent sedimentary transport and deposition in the Nazaré Canyon, Portuguese continental margin. Mar. Geol. 246, 144-164.

De Stigter, H.C. Jesus, C.C., Boer, W., de Jesus Mendes, P.A., Richter, T.O., Costa, A., van Weering, T.C.E., 2011. Recent sediment transport and deposition in the Lisbon-Setubal and Cascais submarine canyons, Portuguese continental margin. Deep-Sea Res. II, Top. Stud. Oceanogr. 58, 2321-2344.

Dullo, W.-C., Flögel, S., Rüggeberg, A., 2008. Cold-water coral growth in relation to the hydrography of the Celtic and Nordic European continental margin. Mar. Ecol. Prog. Ser. 371, 165-176.

Evans, C.D.R., 1984. Cockburn Bank. Solid Geology. 1:250,000 map series. British Geological Survey. 
Evans, C.D.R., 1985. Little Sole Bank and including part of Austell Spur. Sea-bed Sediments. 1:250,000 map series. British Geological Survey.

Evans, C.D.R., 1990. United Kingdom offshore regional report: the geology of the western English Channel and its western approaches. London: HMSO for the British Geological Survey. 93pp.

Evans, C.D.R., Hughes, M.J., 1984. The Neogene succession of the South Western Approaches, Great Britain. J. Geol. Soc. Lond. 141, 315-326.

Folk, R.L., 1954. The distinction between grain size and mineral composition in sedimentary rock

nomenclature. J. Geol. 62, 344-359.

Fonseca, L., Calder, B.R., 2005. Geocoder: An efficient backscatter map constructor. U.S. Hydrogr. Conf. (US HYDRO). San Diego, CA., USA. 29-31 March. Conf. Proc. (www.thsoa.org/hy05/08 3.pdf)

Gori, A., Orejas, C., Madurell, T., Bramanti, L., Martins, M., Quintanilla, E., Gili, J.M., 2013. Bathymetrical distribution and size structure of cold-water coral populations in the Cap de Creus and Lacaze-Duthiers canyons (northwestern Mediterranean). Biogeosci. 10, 2049-2060.

Greene, H.G., Maher, N.M., Paull, C.K., 2002. Physiography of the Monterey Bay National Marine Sanctuary and implications about continental margin development. Mar. Geol. 181, 55-82.

Hall, R.A., Alford, M.H., Carter, G.S., Gregg, M.C., Lien, R.-C., Wain, D.J., Zhao, Z., 2013. Transition from partly standing to progressive internal tides in Monterey Submarine Canyon. Deep-Sea Res. II, Top. Stud. Oceanogr., this issue.

Haq, B.U., Hardenbol, J., Vail, P.R., 1987. Chronology of fluctuating sea levels since the Triassic. Science. 235, 1156-1167.

Harris, P.T., Whiteway, T., 2011. Global distribution of large submarine canyons: Geomorphic differences between active and passive continental margins. Mar. Geol. 285, 69-86.

Heathershaw, A.D., New, A.L., Edwards, P.D., 1987. Internal tides and sediment transport at the shelf break in the Celtic Sea. Cont. Shelf Res. 7, 485-517.

Henry, L. A., Roberts, J. M., 2007. Biodiversity and ecological composition of macrobenthos on cold-water coral mounds and adjacent off-mound habitat in the bathyal Porcupine Seabight, NE Atlantic. Deep-Sea Res. II, Top. Stud. Oceanogr. 54, 654-672.

Hickey, B.M., 1995. Coastal submarine canyons. In: Muller, P., Henderson, D. (eds), Proceedings of the University of Hawaii 'Aha Huliko'a Workshop on Flow Topography Interactions, Honolulu, Hawaii, SOEST Spec. Pub.: 265pp.

Hovland, M., Croker, P.F., Martin, M., 1994. Fault-associated seabed mounds (carbonate knolls?) off western Ireland and north-west Australia. Mar. Pet. Geol. 11, 232-246.

Howell, K.L., Davies, J.S., Narayanaswamy, B.E., 2010a. Identifying deep-sea megafaunal epibenthic assemblages for use in habitat mapping and marine protected area network design. J. Mar. Biol. Assoc. UK 90, 33-68. 
Howell, K.L., Mowles, S., Foggo, A., 2010b. Mounting evidence: near-slope seamounts are faunally indistinct from an adjacent bank. Mar. Ecol. 31, 52-62.

Huthnance, J.M., Coelho, H., Griffiths, C.R., Knight, P.J., Rees, A.P., Sinha, B., Vangriesheim, A., White, M., Chatwin, P.G., 2001. Physical structures, advection and mixing in the region of the Goban Spur. Deep-Sea Res. II, Top. Stud. Oceanogr. 48, 2979-3021.

Huvenne, V.A.I., Masson, D., Wheeler, A., 2009b. Sediment dynamics of a sandy contourite: the sedimentary context of the Darwin cold-water coral mounds, Northern Rockall Trough. Int. J. Earth Sci. 98, 865-884.

Huvenne, V.A.I., Van Rooij, D., De Mol, B., Thierens, M., O’Donnell, R., Foubert, A., 2009a. Sediment dynamics and palaeo-environmental context at key stages in the Challenger col-water coral mound formation: clues from sediment deposits at the mound base. Deep-Sea Res. I, Oceanogr. Res. Pap. 56, 22632280 .

Huvenne, V.A.I., Tyler, P.A., Masson, D.G., Fisher, E.H., Hauton, C., Hühnerbach, V., Le Bas, T.P., Wolff, G.A., 2011. A picture on the wall: innovative mapping reveals cold-water coral refuge in submarine canyon. PLoS ONE. 6, e28755.

Jézéquel, N., Mazé, R., Pichon, A., 2002. Interaction of semidiurnal tide with a continental slope in a continuously stratified ocean. Deep-Sea Res. 49, 707-734.

Jones, J.B., 1992. Environmental impact of trawling on the seabed: a review. New Zealand J. Mar. Freshwat. Res. 26, 59-67.

Kenyon, N.H., Stride, A.H., 1970. The tide-swept continental shelf sediments between the Shetland Isles and France. Sedimentology. 14, 159-173.

Lastras. G., Canals, M., Amblas, D., Lavoie, C., Church, I., De Mol, B., Duran, R., Calafat, A.M., Hughes-Clarke, J.E., Smith, C.J., Heussner, S., and "Euroleón" cruise shipboard party, 2011. Understanding sediment dynamics of two large submarine valleys from seafloor data: Blanes and La Fonera canyons, northwestern Mediterranean Sea. Mar. Geol. 280, 20-39.

Le Boyer, A., Charria, G., Le Cann, B., Lazure, P., Marié, L., 2013. Circulation on the shelf and the upper slope of the Bay of Biscay. Cont. Shelf Res. 55, 97-107.

Le Danois, E., 1948. Les profondeurs de la mer. Trente ans de recherché sur la faune sous-marine au large des côtes de France, Payot, Paris.

Lo lacono, C., Sulli, A., Agate, M., Lo Presti, V., Pepe, F., Catalano, R., 2011. Submarine canyon morphologies in the Gulf of Palermo (Southern Tyrrhenian Sea) and possible implications for geohazard. Mar. Geophys. Res. 32, 127-138.

Long, D., 2006. BGS detailed explanation of seabed sediment modified Folk classification. http://ec.europa.eu/maritimeaffairs/emodnet/documents/standards/mesh geology.pdf).

Martin, J., Puig, P., Palanques, A., Masqué, P., García-Orellana, J., 2008. Effect of commercial trawling on the deep sedimentation in a Mediterranean submarine canyon. Mar. Geol. 252, 150-155. 
Martin, J., Puig, P., Palanques, A., Ribó, M., 2013. Trawling-induced daily sediment resuspension in the flank of a Mediterranean submarine canyon. Deep-Sea Res. II, Top. Stud. Oceanogr, this issue. DOI: 10.1016/j.dsr2.2013.05.036

Masson, D.G., Bett, B.J., Billett, D.S.M., Jacobs, C.L., Wheeler, A.J., Wynn, R.B., 2003. The origin of deepwater, coral-topped mounds in the northern Rockall Trough, Northeast Atlantic. Mar. Geol. 194, 159-180.

Morris. K.J., 2011. North Atlantic octocorals: distribution, ecology and phylogenetics. Unpubl. PhD thesis, Univ. Southampton.

Morris, K.J., Tyler, P.A., Masson, D.G., Huvenne, V.A.I., Rogers, A.D., 2013. Distribution of cold-water corals in the Whittard Canyon, NE Atlantic Ocean. Deep-Sea Res. II, Top. Stud. Oceanogr. 92, 136-144

Mulder, T., Zaragosi, S., Garlan, T., Mavel, J., Cremer, M., Sottolichio, A., Sénéchal, N., Schmidt, S., 2012. Present deep-submarine canyons activity in the Bay of Biscay (NE Atlantic). Mar. Geol. 295-298, 113-127.

Narayanaswamy, B.E., Hughes, D.J., Howell, K.L., Davies, J., Jacobs, C., 2013. First observations of megafaunal communities inhabiting George Bligh Bank, Northeast Atlantic. Deep-Sea Res. II, Top. Stud. Oceanogr. 92, 7986.

Orejas, C., Gori, A., Lo lacono, C., Puig, P., Gili, J. M., 2009. Cold-water corals in the Cap de Creus canyon, northwestern Mediterranean: spatial distribution, density and anthropogenic impact. Mar. Ecol. Prog. Ser. 397, 37-51.

Palanques, A., Durrieu de Madron, X., Puig, P., Fabres, J., Guillen, J., Calafat, A., Canals, M., Heussner, S., Bonnin, J., 2006. Suspended sediment fluxes and transport processes in the Gulf of Lions submarine canyons. The role of storms and dense water cascading. Mar. Geol. 234, 43-61.

Palanques, A., Puig, P., Latasa, M., Scharek, R., 2009. Deep sediment transport induced by storms and dense shelf-water cascading in the northwestern Mediterranean basin. Deep-Sea Res. I, Oceanogr. Res. Pap. 56, 425-434.

Pantin, H.M., Evans, C.D.R., 1984. The Quaternary history of the central and southwestern Celtic Sea. Mar. Geol. 57, 259-293.

Pilskaln, C.H., Churchill, J.H., Mayer, L.M., 1998. Resuspension of sediment by bottom trawling in the Gulf of Maine and potential geochemical consequences. Conserv. Biol. 12, 1223-1229.

Pingree, R.D., Le Cann, B., 1989. Celtic and Armorican slope and shelf residual currents. Prog. Oceanogr. 23, 303-338.

Pingree, R.D., Mardell, G.T., New, A.L., 1986. Propagation of internal tides from the upper slopes of the Bay of Biscay. Nature 321, 154-158.

Puig, P., Canals, M., Company, J.B., Martín, J., Amblas, D., Lastras, G., Palanques, A., Calafat, A.M., 2012. Ploughing the sea floor. Nature 489, 286-290.

Puig, P., Palanques, A., Orange, D.L., Lastras, G., Canals, M., 2008. Dense shelf water cascades and sedimentary furrow formation in the Cap de Creus Canyon, northwestern Mediterranean Sea. Cont. Shelf Res. 28, 2017-2030. 
Reynaud, J.-Y., Tessier, B., Berné, S., Chamley, H., de Batist, M., 1999. Tide and wave dynamics on a sand bank from the deep shelf of the Western channel approaches. Mar. Geol. 161, 339-359.

Roberts, J. M., Long, D., Wilson, J. B., Mortensen, P. B., Gage, J. D., 2003. The cold-water coral Lophelia pertusa (Scleractinia) and enigmatic seabed mounds along the north-east Atlantic margin: are they related? Mar. Pollut. Bull. 46, 7-20.

Roberts, J. M., Wheeler, A. J., Freiwald, A., 2006. Reefs of the deep: The biology and geology of cold-water coral ecosystems. Science. 312, 543-547.

Schlacher, T.A., Schlacher-Hoenlinger, M.A., Williams, A., Althaus, F., Hooper, J.N.A., Kloser, R., 2007. Richness and distribution of sponge megabenthos in continental margin canyons off southeastern Australia. Mar. Ecol. Prog. Ser. 340, 73-88.

Scourse, J., Uehara, K., Wainwright, A., 2009. Celtic Sea linear tidal sand ridges, the Irish Sea Ice Stream and the Fleuve Manche: Palaeotidal modelling of a transitional passive margin depositional system. Mar. Geol. 259, 102-111.

Stewart, H. A., Davies, J. S., 2007. SW Approaches MESH Survey, R/V Celtic Explorer Cruise CE0705, BGS Project 07/06, Operations Report. British Geological Survey Commercial Report, CR/07/123. www.searchmesh.net/PDF/SWApproachesMESHCruiseReport v5 final.pdf

Thierens, M., Titschack, J., Dorschel, B., Huvenne, V.A.I., Wheeler, A.J., Stuut, J.-B., O'Donnell, R., 2009. The 2.6 Ma depositional sequence from the Challenger cold-water coral carbonate mound (IODP Exp. 307): sediment contributors and hydrodynamic palaeo-environments. Mar. Geol. 271, 260-277.

Thrush, S.F., Hewitt, J.E., Funnell, G.A., Cummings, V.J., Ellis, J. Schultz, D., Talley, D., Norkko, A., 2001. Fishing disturbance and marine biodiversity: the role of habitat structure in simple soft-sediment systems. Mar. Ecol. Prog. Ser. 223, 277-286.

Toucanne, S., Zaragosi, S., Bourillet, J.-F., Naughton, F., Cremer, M., Eynaud, F., Dennielou, B., 2008. Activity of the turbidite levees of the Celtic-Armorican margin (Bay of Biscay) during the last 30,000 years: imprints of the last European deglaciation and Heinrich events. Mar. Geol. 247, 84-103.

Tyler, P.A., Zibrowius, H., 1992. Submersible observations of the invertebrate fauna on the continental slope southwest of Ireland (NE Atlantic Ocean). Oceanologica Acta 15, 211-226.

Ulses, C., Estournel, C., Puig, P., Durrieu deMadron, X., Marsaleix, P., 2008. Dense shelf water cascading in the northwesternMediterranean during the coldwinter 2005: quantification of the export through the Gulf of Lion and the Catalan margin. Geophys. Res. Lett. 35, L07610.

Van Rooij, D., Huvenne, V.A.I., Blamart, D., Henriet, J.-P., Wheeler, A., de Haas, H., 2009. The Enya mounds: a lost mound-drift competition. Int. J. Earth Sci. 98, 849-863.

van Weering, T.C.E., Hall, I.R., de Stigter, H.C., McCave, I.N., Thomsen, L., 1998. Recent sediments, sediment accumulation and carbon burial at Goban Spur, N.W. European Continental Margin (47-50 N). Prog. Oceanogr. 42, 5-35.

Veale, L. O., Hill, A. S., Hawkins, S. J., Brand, A. R., 2000. Effects of long-term physical disturbance by commercial scallop fishing on sub-tidal epifaunal assemblages and habitats. Mar. Biol. 137, 325-337. 
Weiss, A.D., 2001. Topographic positions and landforms analysis. In: ESRI International User Conference, San Diego, USA.

Wheeler, A.J., Beyer, A., Freiwald, A., de Haas, H., Huvenne, V.A.I., Kozachenko, M., Olu-Le Roy, K., Opderbecke, J., 2007. Morphology and environment of coldwater coral carbonate mounds on the NW European margin. Int. J. Earth Sci. 96, 37-56.

Wheeler, A.J., Kozachenko, M., Henry, L.-A., Foubert, A., de Haas, H., Huvenne, V.A.I., Masson, D.G., Olu, K., 2011. The Moira Mounds, small cold-water coral banks in the Porcupine Seabight, NE Atlantic: Part A-an early stage growth phase for future coral carbonate mounds? Mar. Geol. 282, 53-64.

Wilson, M.F.J., O'Connell, B., Brown, C., Guinan, J.C., Grehan, A., 2007. Multiscale terrain analysis of multibeam bathymetry data for habitat mapping on the continental slope. Mar. Geod. 30, 3-35.

Wollast, R., Chou, L., 2001. Ocean margin Exchange in the Northern Bay of Biscay: OMEX I. An introduction. Deep-sea Res. II, Top. Stud. Oceanogr. 48, 2971-2978.

Wright, D.J., Lundblad, E.R., Larkin, E.M., Rinehart, R.W., Murphy, J., Cary-Kothera, L., Draganov, K., 2005. ArcGIS Benthic Terrain Modeler. Oregon State University, Davey Jones Locker Seafloor Mapping/Marine GIS Laboratory and NOAA Coastal Services Center, Corvallis, OR, USA.

Zaragosi, S., 2001. Les systems turbiditiques profonds de la marge celtique-armoricaine (Golfe de Gascogne): physiographie et evolution au cours des derniers 30000 ans. Unpubl. PhD thesis, Univ. Bordeaux 1, ñ2264, $291 \mathrm{pp}$.

Zaragosi, S., Auffret, G.A., Faugères, J.-C., Garlan, T., Pujol, C., Cortijo, E., 2000. Physiography and recent sediment distribution of the Celtic Deep-Sea Fan, Bay of Biscay. Mar. Geol. 169, 207-237.

Zaragosi, S., Bourillet, J.-F., Eynaud, F., Toucanne, S., Denhart, B., Van Toer, A., Lanfumey, V., 2006. The impact of the last European deglaciation on the deep-sea turbidite systems of the Celtic-Armorican margin. Geo-Mar. Lett. 26, 317-329. 